\title{
Complex state ownership, competition, and firm performance - Russian evidence
}

\author{
Eva Liljeblom \\ Department of Finance and Statistics, \\ Hanken School of Economics, Helsinki, Finland and \\ Lund School of Economics and Management (LUSEM), \\ Lund University, Lund, Sweden, and \\ Benjamin Maury and Alexander Hörhammer \\ Department of Finance and Statistics, \\ Hanken School of Economics, Helsinki, Finland
}

\begin{abstract}
Purpose - State ownership has been common especially in industries with restricted competition. In Russia, state-controlled firms represent around 41 percent of the market value of all listed firms (Deloitte, 2015). Yet, there is a significant gap in the literature regarding the effects of various forms of government control in listed firms. The purpose of this paper is to fill this gap by exploring the impact of the complexity of state ownership and competition on the performance of Russian listed firms.

Design/methodology/approach - The sample consists of data for 72 firms (360 firm-years) in the Russian MOEX broad market index during 2011-2015. The complexity of state ownership is captured by studying forms of state control including majority/minority, direct/indirect, federal/regional, mixed structures and golden shares. Findings - The authors find significant differences in performance relating to different forms of state ownership. State control is negatively related to firm valuation and the sales/employees ratio. Performance is weakest when state ownership takes the form minority, regional or direct ownership. State control through golden shares typically outperforms other state-controlled firms. The authors find indications of employment prioritization beyond the economical optimum. In addition, the relation between state ownership and profitability becomes positive in sectors where state firms appear to enjoy lower competition.

Originality/value - While the effects of state ownership have been studied on many markets, there is a lack of studies on the effects of different forms, or the complexity, of state ownership beyond direct and indirect ownership. The authors contribute to the literature on the performance effects of state ownership by studying a multitude of forms of governmental ownership as well as the role of competition in Russia. Especially the profitability of state-controlled firms is significantly affected by industry characteristics. Implications of the results are discussed both from firm and policy maker perspectives.
\end{abstract}

Keywords Firm performance, State ownership, Competition, Russian owners

Paper type Research paper

\section{Introduction}

State ownership has been common especially in sectors with restricted competition and entry barriers. Studies of the performance of state-owned enterprises typically find that state ownership negatively affects firm profitability, efficiency and market valuation (Boardman and Vining, 1989; Megginson et al., 1994; Dewenter and Malatesta, 2001)[1]. However, studies on developing countries such as Russia, China, and India indicate more

JEL Classification - G31, G34

(C) Eva Liljeblom, Benjamin Maury and Alexander Hörhammer. Published by Emerald Publishing Limited. This article is published under the Creative Commons Attribution (CC BY 4.0) licence. Anyone may reproduce, distribute, translate and create derivative works of this article (for both commercial and non-commercial purposes), subject to full attribution to the original publication and authors. The full terms of this licence may be seen at http://creativecommons.org/licences/by/4.0/legalcode

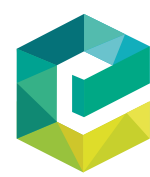

International Journal of Emerging Markets Vol. 15 No. 2, 2020 pp. $189-221$ 
IJOEM

15,2

mixed effects (Kuznetsov and Muravyev, 2001; Muravyev, 2002; Sun et al., 2002; Gupta, 2005; Ang and Ding, 2006; Okhmatovskiy, 2010; Yu, 2013; Vanteeva and Hickson, 2016)[2]. Still today, state-owned enterprises represent about 10 percent of the global GDP and about 20 percent of the global market value of listed firms (Bruton et al., 2015), and typically a higher fraction in developing countries.

While the effects of state ownership have been studied on many markets, there is a surprising lack of studies on the effects of different forms, or of the complexity of state ownership that would take a holistic view, although such studies could have important policy implications. Typically, a separation between direct and indirect ownership has been made in the literature. The examples of studies on Russian firms, which to some extent have investigated different forms, are Okhmatovskiy (2010) and Muravyev (2002). We contribute to the literature on the performance effects of state ownership by studying a multitude of forms of governmental ownership in Russia during 2011-2015. We study the outcomes of ownership patterns using several measures for firm performance, and using a data set including all firms in the MOEX broad market index (100 listed shares, including both shares for firms with and without some state ownership). State control is associated with significantly lower valuations and sales/employment efficiency. We also find significant differences in performance relating to different forms of state ownership. Performance is poorest when state ownership takes the form minority and regional ownership. State control through golden shares tends to significantly outperform firms without state ownership. We also find the indications of employment prioritization beyond the economical optimum (from the firm's point of view) in state-owned firms. In addition, our results indicate that the relation between state ownership and profitability becomes positive in sectors where state dominance is high and competition low, although valuation levels are not significantly different. Finally, we find that such differences are persistent over time and exist both prior to, and during, periods of economic sanctions against Russia. Our results are of both scientific interest concerning the existence of agency problems related to state ownership, and of practical interest for investors on the Russian market.

The Russian market features high ownership concentration and an important presence by the state in various forms of governmental ownership. Although state ownership fell dramatically from the Soviet Union times, state involvement is still high. It has been estimated that state-controlled firms represent around 41 percent of the market value of all listed Russian firms (Deloitte, 2015). Although the Russian state has emphasized that the privatization continues (Tompson, 2008), Djankov (2015) comments that the Russian state since 2003 has turned its privatization policy around and increased its control of sectors considered to be of strategic importance, such as finance, energy, transportation and media. According to Chernykh (2008), the control by the Russian state is often opaque, as only direct ownership is typically reported. Indirect ownership through pyramids can be inferred, but requires much work. State ownership can be majority or minority ownership, and it can be exercised through multiple channels such as through federal or regional institutions, or by the use of so-called golden shares, which give certain control rights but no rights to cash flows from the firm. Also, the forms of government regulation and the incentive structures for managers of public firms can vary.

The results in this paper fit rather well with some related literature. The finding of relatively low performance of Russian firms controlled primarily by regional governments is consistent with the difficulty of supervising regional governors (Blanchard and Shleifer, 2001), more self-dealing by regional firms as in China (Cheung et al., 2010), and the conflicts between regional and federal powers in Russia (Nelson and Kuzes, 2002). However, when regional control is combined with federal control, state control showed higher performance than private ownership control (though not significantly so), which supports the idea that multiple large shareholders with diverging interests may monitor each other (Maury and 
Pajuste, 2005). Relatedly, the result that minority state ownership underperforms majority control by the state appears related to majority control of strategic assets that result in monopolies (Shleifer, 1998). Empirically, Muravyev (2002) finds that strategic state ownership performs better than other state ownership, while Yu (2013) finds that Chinese majority state control is associated with more political benefits and thus outperformance compared with minority ownership. For GCC countries, Abdallah and Ismail (2017) document that the positive effects from corporate governance on performance are highest when the majority shareholders are the government or local corporations[3]. Overall, the performance effects of state control in Russia seems to depend on the ownership form such as relative size, the type (e.g. regional or federal), direct vs indirect ownership, and competition. Our study suggests policy implications concerning, for example, the governance of regional ownership.

The remaining part of the paper is structured as follows. In Section 2, we describe the Russian economy and state ownership in Russia. In Section 3, we review relevant theory and empirical literature, and develop testable hypotheses. Data and methodology are presented in Section 4. In Section 5, we present the results from our empirical analysis. Section 6 provides first a discussion of the results and offers some general and policy implications, and finally summarizes the paper.

\section{The institutional setting in Russia}

The purpose of this section is to present institutional details relevant for our study, i.e. state ownership and corporate governance in Russia. However, since the country has undergone large changes during the last decades, we start by providing an brief overview of the Russian economy, as well as of the privatizations, which lay the fundament to what we now study, i.e. stock listed companies where the government still often has kept some ownership stake.

\subsection{The Russian economy}

The Russian economy grew fast between the two financial crises of 1998 and 2009, with a cumulative GDP growth of 83 percent and a cumulative increase in productivity of 70 percent. The growth was largely fueled by exports of oil and gas. Since 2009, growth has slowed down, with an average GDP growth of only 1.5 percent for the years of 2009-2014 (Djankov, 2015). The Ukranian crisis led to severe sanctions against Russia. It started in 2013, with an internal crisis in Ukraina connected to the decision of whether Ukraina should get closer to the European Union, and led to the president (who would not sign the contract) being fired. Russian troops then invaded Crimea, and after a poll, Crimea was declared part of Russia. Only 11 countries have accepted the results of the poll, whereas 100 have declared it not valid. Since Russia did not back off, the Western countries, led by the USA, decided to undertake economic sanctions against Russia (Wang, 2015). These sanctions have increased in scope over the years, and include actions from the freezing of certain Russian accounts (of both private persons as well as institutions) abroad, to reduced co-operation (including trade boycotts) with Russia in the sectors of energy, finance, and defense. Russia has answered with sanctions against certain Western goods. As a consequence of such sanctions, the Russian economy has declined, and Russia has started to look East in its trade relations.

Our study period spans from 2011-2015. We will also separately study the effects of state ownership before and during the time period of the economic sanctions against Russia.

\subsection{Privatizations in Russia}

After the collapse of the Soviet Union, a mass privatization was initiated in Russia in 1992, in which Russian citizens could through coupons buy shares in the companies to
Complex state ownership 
IJOEM

15,2

192

be privatized. In September 1993, already 20 percent of the industrial workers were employed in privately owned firms, and more that 60 percent of the population was in favor of a continued privatization (Boycko et al., 1993). The privatization process led to a concentration of ownership in the hands of managers, since the workers typically were rather passive with their ownership, and often sold out. Also some illegalities took place (Black et al., 1999). Another wave took place through the "loan for shares" program in 19951996[4]. In that program, some businessmen bought majority stakes in Russian state-owned firms. Many so-called oligarchs[5] got their ownership stakes in connection with this program (Guriev and Rachinsky, 2005), but not all. In summary, the privatization was most active during 1992-1996 and in that process, about 43,000, 22,000, 10,000 and 5,000 firms were privatized during the years of 1993, 1994, 1995 and 1996, respectively.

As a consequence of the way the privatizations were conducted, the concentration of ownership in Russia is high, and has been increasing over time. According to a study by Deloitte (2015), among 120 listed Russian firms, 73 percent had a majority owner in 2015, while the corresponding number in 2012 was 65 percent. As many as 95 percent of the firms had a large owner owning at least 25 percent of the equity in 2015. The weak rule of law in Russia has been suggested as a factor contributing to the high concentration of ownership (Lazareva et al., 2007). In a weak rule of law environment, a strong owner can better control the management and reduce agency problems of type one (i.e. between managers and shareholders). Naturally, the benefits of self-dealing may also attract wealthy owners to concentrate their ownership.

The mass privatization was mostly completed in 1997 (Pinto and Ulatov, 2010). However, the Russian state has continued to privatize companies since that. Official statistics from the Central Statistics Office in Russia indicate that the proportion of state-owned enterprises has continued to go down, as shown in Table I. That data have, however, some problems. First, it counts only directly state-owned firms, and not companies owned by another state-owned firm through a pyramid structure. Second, many Russian firms have a mixed ownership structure so that the state owns a majority of the shares but not all of them. Third, many state-owned firms are quite big. Thus the statistics in Table I makes privatization seem bigger than what it actually is. Lately, privatization has also taken a step back through the nationalization of Yukos as well as increased state control in many strategically important sectors such as oil, the airline industry, building and construction, energy, machinery, and the financial sector (Djankov, 2015).

\begin{tabular}{|c|c|c|c|c|}
\hline & 2000 & 2005 & 2010 & 2015 \\
\hline Number of firms and organizations (thousands) & 3346.5 & 4767.3 & 4823.3 & 5043.6 \\
\hline Fully state-owned & $11.0 \%$ & $8.7 \%$ & $7.6 \%$ & $6.4 \%$ \\
\hline Fully private & $75.0 \%$ & $80.5 \%$ & $85.1 \%$ & $86.8 \%$ \\
\hline Organizations & $6.7 \%$ & $5.3 \%$ & $3.3 \%$ & $2.9 \%$ \\
\hline Other (such as mixed, foreign) & $7.4 \%$ & $5.6 \%$ & $4.1 \%$ & $3.9 \%$ \\
\hline Capital investments (billions of RUB) & 1165.2 & 3611.1 & 9152.1 & 14555.9 \\
\hline Fully state-owned & $28.4 \%$ & $22.6 \%$ & $21.0 \%$ & $16.3 \%$ \\
\hline Fully private & $29.9 \%$ & $44.9 \%$ & $57.0 \%$ & $59.5 \%$ \\
\hline Organizations & $27.8 \%$ & $12.9 \%$ & $7.5 \%$ & $9.1 \%$ \\
\hline Other (such as mixed, foreign) & $13.9 \%$ & $196 \%$ & $14.5 \%$ & $15.1 \%$ \\
\hline Employees (millions) & 71.9 & 64.5 & 66.7 & 68.5 \\
\hline Fully state-owned & $69.1 \%$ & $37.8 \%$ & $33.5 \%$ & $27.7 \%$ \\
\hline Fully private & $19.3 \%$ & $46.1 \%$ & $54.3 \%$ & $62.0 \%$ \\
\hline Organizations & $10.5 \%$ & $12.6 \%$ & $7.8 \%$ & $5.1 \%$ \\
\hline Other (such as mixed, foreign) & $1.1 \%$ & $3.5 \%$ & $4.4 \%$ & $5.2 \%$ \\
\hline
\end{tabular}

Table I.

State ownership, capital investments and employees in Russia 2000-2015

Source: The Russian Central Statistics office. gks.ru, 2016 


\subsection{Corporate governance in Russia}

The corporate environment in Russia is characterized by hidden and anonymous ownership structures. When ownership in strongly concentrated, and minority protection weak, the opaqueness of ownership creates an additional barrier for the enhancement of lender's rights, and for criminal charges. It also reduces shareholder activism. Another problem is the low enforcement of laws, due to corruption in courts, regulatory bodies, and the police (Lazareva et al., 2007). The weak corporate governance has at intervals led to conflicts such as battles concerning corporate ownership, and the overtaking of minority investors' assets (Dyck et al., 2008).

Lately, the press for good governance has been increasing (Okhmatovskiy and David, 2012), and also led to big improvements in both corporate governance as well as minority protection (Deloitte, 2015). The Federal Commission for the Stock Market (FCSM) gave out new guidelines for corporate governance in 2014. It is voluntary but highly recommended to follow them ("comply or explain" is recommended). Official state documents emphasize the need to improve the governance of state-controlled listed firms. The targets include restructuring of ownership so that the Russian state in the future would only own assets in strategically important sectors, and to develop the dividend policies in the firms and to make them clearer (economy.gov.ru, 2017a, b). According to the OECD (2015), one of the biggest problems with state ownership in Russia is the coordination between the different representatives of the state when it comes to the strategic development of the firm. More effect is put into the annual financial results accounting wise, i.e. on how much of it belongs to the state, than on strategic goals.

According to a study by World Bank (2017), Russia placed as number 53 among 190 countries when measured by a score for protecting minority investors. Besides governmental reforms that have taken place over the recent years, many firms have also created their own corporate governance guidelines. However, how much of this is window dressing instead of real improvements, is uncertain (Okhmatovskiy and David, 2012). Black et al. (2006) have, among others, reported results indicating that there is a positive impact of good governance on firm value in Russia.

\subsection{State ownership in Russia}

The Russian economy is dominated by five sectors with large state ownership: infrastructure (trains transports, pipelines, and nuclear power), resource extraction (oil, gas, and diamonds), defense industry, the financial sector, and media (Sprenger, 2010). A study by Deloitte (2015) tells that, within a sample of 120 listed Russian firms in 2015, about 41 percent of the aggregate market value of the sample firms was controlled by the Russian state. In our sample of large Russian listed firms during 2011-2015, the Russian state is a majority owner in about 35 percent of the firms, which corresponds to about 42 percent of the aggregate market value of the sample firms[6].

The Russian state can be either a majority or a minority owner in companies, and can own companies/parts of companies either directly, or through a firm or several firms /chains of firms (i.e. through indirect ownership through pyramiding). Chernykh (2008) studied the ultimate ownership of Russian listed firms in 2008. Her study shows the importance of taking indirect ownership into account. When looking only at direct ownership, the state was the largest owner in only 14 percent of the sample. Chernykh comments that as compared to previous times, state ownership in many cases had only changed form, so that above all the right to cash flows has been reduced. When also indirect ownership was taken into account, the Russian state was a majority owner in 37 percent of the sample, and controlled at least 25 percent of the votes in 48 percent of the sample. The Russian state seems to be more active with pyramidal ownership as compared to other owners (Chernykh, 2008). 
IJOEM

15,2

194

The Russian state can own assets both at the federal as well as at the regional level[7]. Most assets are, however, owned at the federal level. The regional level is not, however, unimportant. In the study by Chernykh (2008), 9.4 percent of the listed firms in her sample were controlled by regional authorities. When a Russian regional authority is one of the owners of a firm, it may have targets that are different from the other owners of the firm. One example is the focus on employment. Lazareva et al. (2007) mentions AvtoVaz (the producer of LADAs), that for long was run without layoffs even though it experienced declining market shares. AvtoVaz is important for the town of Toliatti, in which about 20 percent of the residents are employed by that firm. Sharafutdinova and Kisunko (2014) studied 85 Russian regions in 2014 and report that the governors of the regions have significant power in economic policy, and that although all regions should follow federal laws, there are large differences between them, and the following of unofficial laws is rather common. Also Blanchard and Shleifer (2001) see many problems with the economic policy in the regions, and think that the governors should be better supervised. According to Remington (2012), the collapse of the Soviet Union led to reduced federal power in the regions[8].

The so-called golden shares are a special feature in Russia and some other countries. These shares facilitate control in strategically important companies without giving rights to cash flows. They are often valid an unlimited time but may also have an expiry date. Such shares exist also in other countries in various forms (see Bortolotti and Faccio, 2009; Vining and Weimer, 2016). In Russia, these are often in use in the companies that were privatized early. Through these, the Russian state can access a veto right over important corporate restructurings, and nominate some board member(s) (Chernykh, 2008).

\section{Theoretical framework and hypothesis development}

\subsection{Key tradeoffs}

The analysis of the consequences of state ownership in publicly traded firms starts with a costs and benefits analysis. State control may enable the extraction of non-market rents including preferential treatments in competition for government contracts, access to finance and raw materials, and they may face lower regulatory oversight (e.g. Faccio, 2006). Politicians will extract at least some of the non-market rents generated by political connections, and this will be beneficial to corporate value only when marginal benefits exceed their marginal costs (Shleifer and Vishny, 1994). Furthermore, various forms of state ownership will give rise to agency problems between shareholders and managers as well as agency problems between controlling shareholders and minority shareholders (e.g. Shleifer and Vishny, 1997). In addition, the lower competition in certain state-dominated sectors may result in high profits and thus outweigh the negative effects of state ownership arising from agency problems. The net effect of state ownership on firm profitability, valuation, and efficiency becomes an empirical question as we discuss in more detail below.

\subsection{Agency problems}

The separation of ownership and control may lead to agency problems (Jensen and Meckling, 1976). Agency problems are often classified into two types: the ones between owners and management (type 1), and those between controlling and minority owners (type 2), or, more generally, between different types of owners. We focus on the latter one. Agency problems between owners have been in the focus of many studies on developed and developing markets during the last decades (e.g. Maury and Pajuste, 2005). A big owner may extract private benefits from the firm, thanks to majority control of equity or votes, the latter by the means of dual shares (Grossman and Hart, 1988). The methods for extracting private benefits include self-dealing and tunneling of assets (Djankov et al., 2008). 
Shleifer and Vishny (1997) list some typical methods of self-dealing, such as internal pricing, dilution of other owners, undertaking projects that give private benefits, personal loans, and direct theft. There is both indirect and direct empirical evidence supporting the idea that various kinds of self-dealing methods are practiced. The examples of indirect evidence are the price differences between control blocks and other shares, and between dual-class shares (see, e.g. Dyck and Zingales, 2004). More direct evidence in the form of various transactions is provided, for example, by Dyck et al. (2008) on Russian data. Dyck and Zingales (2004) note that most of the global cases of self-dealing probably go unnoticed, but that good accounting practices, strong minority investor protection, media following and strong tax enforcement are associated with lower amounts of private benefits due to such agency problems[9].

A state represents a specific form of owner that due to its legislatorial and other powers may create agency problems of Type 2 even when its ownership stake is small. This happens when the interests of the governmental owner differs from those of the other owners (see also e.g. Vining and Weimer, 2016). The state may as an owner, for example, prefer employment beyond what is optimal from the viewpoint of the specific firm, i.e. beyond what maximizes firm value, since unemployment brings other costs to the state. Shleifer and Vishny (1994) note that state-owned enterprises often are associated with higher wages and salaries and more workers per output as compared to other firms[10]. The state can also prefer the supply of certain services (such as energy, infrastructure, telecom, or cultural services) for the population beyond what is optimal from a pure economic perspective for the firm (Okhmatovskiy, 2010)[11]. Another problem appears if the politicians steer the firm without significant cash flow rights, and make decisions that maximize the benefits of themselves (or their voters) instead of the owners (Shleifer and Vishny, 1997). This may lead to steering projects to certain contractors, independent of what is most profitable for the firm. Third, the lacking incentives and business knowledge of the politicians may also lead to misalignments. The state may appoint as its representative on the board persons involved in regulating the industry in question, which causes conflicts of interest (Tompson, 2008). A specific form of conflict of interest is caused by taxation, since taxes represent a cost for the firm, but an income for the state (Bradshaw et al., 2016).

It is well known that the state may have other goals than just shareholder maximization. Such other goals may, for example, be related to employment or other social considerations. The state as an owner may, out of social concerns, work for involving firms parallel to the state in the maintenance of employment in a region, or the employment motivation may be fueled by the wish of bureaucrats and politicians to obtain voters in a region (e.g. Shleifer and Vishny, 1997). Relatedly, Guriev and Rachinsky (2005) report not only that several oligarchs' conglomerates expressed needs for cutting employment by at least on half to become internationally competitive with global industry leaders, but also that political constraints hindered large employment changes in oligarch and state-owned firms (Guriev and Rachinsky, 2005). In addition, state firms are also often heavy polluters (Shleifer and Vishny, 1997). The political contacts by the firms may give benefits (see Faccio, 2006) while other goals related to political and social considerations may lead to negative performance effects.

Agency problems due to differing interests between owners can naturally be mitigated by corporate governance, for example by strong boards and optimal managerial incentive contracts. However, state control has often been associated with weak governance and poor managerial incentives (Okhmatovskiy, 2010). On the other hand, some contrary views on the benefits of governmental ownership on corporate governance are offered, for example, by Abdallah and Ismail (2017) for the GCC countries. Relatedly, Borisova et al. (2012) find that state ownership is associated with weaker corporate governance but only in countries with less protective legal systems. The management in state-owned firms has also often been 
IJOEM

15,2

196

viewed as protected from the disciplining effects of market forces, as the state has been passive in its supervisory role (OECD, 2015). Corporate governance is often complicated in state-owned enterprises, as there can be many participants involved (the management, the board, possibly also a supervisory board, the private owners, the Ministries, the politicians, the state, etc. (OECD, 2015)). The agency costs can therefore be large; there can be many differing opinions, and decision-making may become slow.

\subsection{Non-market rents from state ownership}

State ownership may, however, also bring benefits to the firm. First, the management of such firms may get access to private information on planned laws and regulations, and may even influence these. Hillman (2005) found in a global study that firms with politicians in the board have significantly better performance, and that it was more common with politicians in the board in the more heavily regulated industries. The net benefit after agency costs of such influence may be larger for indirectly controlled firms (Okhmatovskiy, 2010). Also OECD (2015) notes that harmful legislation is less common against state-owned enterprises as compared to others. Puffer and McCarthy (2007) observe that Russian governmental officers often help politically friendly businessmen and punish the unfriendly. Lazzarini and Musacchio (2018) maintain that state-controlled firms can gain from non-market rents including subsidies, preferential credit and operation rights. Second, the access of public financing, and the chances for receiving public orders, may also be better in state-owned firms (Okhmatovskiy, 2010). Third, Kuznetsov and Muravyev (2001) suggest that state ownership may also introduce control of the other large owners in firms with state ownership, so that the risk for the expropriation of minority owners is reduced. These benefits can be expected to be larger in countries with weaker rule of law and higher corruption[12].

\subsection{State control and competition}

The strategic motives for state ownership may lead to a relation between state control and performance that is not primarily related to agency problems but rather to strategic sector effects such as reduced competition. In certain sectors, reduced competition may be a more important driver of performance than the corporate governance structure. Just like state aid may distort competition, state control of a whole sector may lead to the absence of competition and enable monopolistic rents. Profits may not be the primary concern for state firms (Shleifer and Vishny, 1997). However, the Russian state has a large interest in sectors featured by monopolistic rents (see Federal Agency for State Property Management), and the goal is to retain important state ownership only in strategically important sectors in the future (economy.gov.ru, 2017a). For example, state involvement in the oil, power and mineral-ore sectors is important. Guriev and Rachinsky (2005) show that private industrial groups and oligarchs, also present in many state-dominated sectors, tend to run their empires more efficiently than the state and other owners. In sum, since state ownership typically is higher in sectors with natural monopolies or barriers to entry, there can be a link between state ownership and firm profitability driven by primarily by lack of competition rather than corporate governance. Therefore, we also study differences between extractive and non-extractive industries.

\subsection{Empirical evidence}

Most studies of state vs private ownership on developed markets indicate that the negative consequences of state ownership outweigh the potential benefits (Boardman and Vining, 1989; Dewenter and Malatesta, 2001; Boubakri et al., 2008). For East Asia, Boubakri et al. (2018) find that non-majority state-owned firms have higher valuations than non-state-owned firms. 
For China, Yu (2013) find some indications toward positive effects of state ownership on performance, as do Ang and Ding (2006) for Singapore. Prior studies of state ownership in Russia have produced somewhat mixed evidence and also indicated that there are some differences in the performance effects of different forms of state ownership. Kuznetsov and Muravyev (2001) and Vanteeva and Hickson (2016) found positive effects from state ownership in Russia, the latter for firms with mixed ownership (with both state and private owners). A negative effect is supported by Guriev and Rachinsky (2005), who found a significantly lower productivity growth in 2001 in state-owned firms as compared to other firms. Also Muravyev (2002) found support for a negative relationship between state ownership and performance in Russia. Okhmatovskiy (2010) separated between direct and indirect ownership of banks, and found that the indirectly state-controlled ones were more profitable. Abramov et al. (2017) studied state ownership in large Russian firms during 2006-2014, and found support for benefits from private ownership, as well as from indirect state ownership as compared to direct state ownership. Their study is, however, restricted to looking at the development of individual performance measures over the years.

\subsection{Hypotheses}

Our overall research question is whether different forms of governmental ownership have different effects on firm performance in the case of Russian listed firms where there are also other owners present. Based on studies on developing markets and some on emerging markets, we expect that state ownership through the agency problems it brings, has an overwhelmingly negative effect on firm performance. Based on Okhmatovskiy (2010) and Cheung et al. (2010), we also expect that it is the direct ownership form that is the main carrier of these harmful effects on performance and thus significantly negatively related to the performance variables (while indirect ownership, which we also control for, may have a more ambiguous effect). Hence, even if we do not find a significant negative effect for the state control variable, we expect to find one for the direct state control dummy variable:

H1. State ownership has a negative impact on firm performance.

H2. Direct state ownership has a negative impact on firm performance.

Based on our discussion of potential agency problems between regional authorities and other owners, and the results of, e.g., Cheung et al. (2010) who found more self-dealing among regionally (rather than federally) controlled Chinese firms, we expect that especially state ownership through regional authorities is harmful for firm profitability, value and efficiency. Lazareva et al. (2007) present an example of regional authorities preferring employment to profitability, giving additional reason to expect that regional state ownership is negatively related especially to the employment-based performance (i.e. efficiency) measure of sales/employee:

H3. Regional state ownership is negatively related to firm performance.

Since golden shares give the Russian state a veto right to certain decisions but no cash-flow rights, we expect that if state ownership comes in such a form, it can mitigate the otherwise negative effects of state ownership. In a test setting, where the general effects of state ownership is already captured by some ownership variable, we therefore expect that a dummy for golden shares becomes positive, indicating that golden shares would reduce the negative effects of state ownership:

H4. State control through golden shares has a non-negative effect on firm performance.

If state-controlled firms over perform in some sectors but not in others while controlling for corporate governance structures, there are strong reasons to believe that other than agency 
IJOEM

15,2

198

considerations are affecting the results. Thus, we expect the performance of state-controlled firms to have higher performance in sectors that are of strategic national interest and where state firms operate in a monopolistic setting. There may also be variations in performance due to corporate governance differences within sectors with state dominance, and because listed companies have other that state owners:

H5. State ownership is positively related to firm performance in non-competitive industries.

\section{Data and methodology}

\subsection{Data}

We use panel data for the years 2011-2015 for firms in the Russian MOEX broad market index, which is the main rubel-denominated (broad) benchmark index for the Russian stock market. Of the 100 shares in the index, 28 were excluded due to the following reasons: financial firms (7), firms with dual shares (13) and lack of data (8). The remaining sample thus consists of data for 72 firms (360 firm-years). Data for firm financials and ownership structures are obtained from FactSet. Information on historical changes in key shareholdings is shown in FactSet. The ultimate shareholder types are typically clear, but to cross-check ownership structures and to find the ultimate owners (in the question of pyramidal ownership) we use information from internet pages (including government web pages, such as those related to the Federal Agency for State Property Management, and publications) and other information from the web. Data on listings on other markets have been manually collected from annual corporate reports, FactSet and the internet. Data on the number of employees are from FactSet (about 40 percent of the information), from other data sets (Orbis and Eicon, about 10 percent), and corporate annual reports and internet pages (the remaining about 50 percent).

Data on golden shares have been collected from corporate annual reports and corporate web pages. Most of our sample firms comment in their annual statements whether the Russian state has a golden share in the firm, while some firms do not comment on golden shares. We sent an e-mail to the Russian Central Statistics Office to get more information concerning the firms that do not say anything about golden shares. The representative for the office (at stat@gks.ru, 2017) told that company-specific information about the existence of golden shares is not publicly available, but that the number of public joint stock companies (PJSCs) with golden shares is 88 on January 1, 2016[13]. In total, 20 firm-year observations in our sample (representing 4 different firms) have golden shares according to data available to us. It is important to note that our golden share variable reflects publicly available information, which means that there may be firms with undisclosed golden shares in place.

\subsection{Methodology and variable description}

In order to test whether state ownership is related to firm performance, we estimate separate pooled OLS (panel data) models for each of our firm performance measures, one by one, including as explanatory variables our state ownership test variables from $\mathrm{H1}-\mathrm{H} 4$, together with some other ownership controls in specification tests, as well as traditional controls. Such models are typical in studies of corporate governance or ownership effects on firm value or performance, such as in Dewenter and Malatesta (2001), Boardman and Vining (1989) and Black et al. (2006). As the time dimension in our study is thin as compared to the cross-sectional dimension, using full fixed effects (FE) is not motivated[14]. However, we include time and sector dummies in all models and estimate robust standard errors that control for clustering at the firm level[15]. The models are of the following form with one-year lagged independent variables:

$$
Y_{i, t}=\alpha+\beta_{1} \text { State }_{i, t-1}+\beta_{2} C_{i, t-1}+\varepsilon_{i},
$$


where $Y_{i}$ is a performance variable: either profitability (ROA, ROE or ROS), a valuation variable (Tobin's $Q$ ), or an efficiency measure (Sales/Employee), State ${ }_{i}$ is a vector of state control variables and $C_{i}$ is a vector of control variables specific to that model specification. We include time and sector dummies in all models where applicable. Next, we explain our variables in more detail.

To estimate the role of competition in the state ownership-performance relation, we estimate the following model:

$$
\begin{aligned}
Y_{i, t}=\alpha & +\beta_{1} \text { State }_{i, t-1}+\beta_{2} \text { State }_{i, t-1} \times \text { Extractive industries }_{i, t-1} \\
& +\beta_{3} \text { Extractive industries }_{i, t-1}+\beta_{4} C_{i, t-1}+\varepsilon_{i},
\end{aligned}
$$

where the extractive industries dummy variable equals one for oil, gas, minerals, steel, mining and energy sectors, and zero otherwise. Model 2 includes time dummies but not industry dummies other than the extractive industry dummy.

4.2.1 Dependent variables. We measure firm performance with proxies for profitability, valuation, as well as efficiency. First, in line with Dewenter and Malatesta (2001), and Boardman and Vining (1989), we include the profitability measures of ROA (the return on assets measured as the net operating profit divided with total assets), ROE (the return on equity (ROE) measured as net income divided by equity), and ROS (the return on sales (ROS), defined as EBIT divided by total sales)[16]. Observations with negative equity have been omitted (in line with Dewenter and Malatesta, 2001). Second, we include the valuation measure of Tobin's $Q$, defined as the market value of the firm divided by the book value of total assets, in line with Kuznetsov and Muravyev (2001), Muravyev (2002), Vanteeva and Hickson (2016) and Yu (2013). Third, following Boardman and Vining (1989) and Wei et al. (2002), we include the efficiency measure Sales/Employee, defined here as total sales (billions of rubles) divided by the number of employees (measured in thousands). Sales per employee measures employee productivity, and is used to test for potential outcomes from social motives for state ownership, or alternatively, inefficiency due to agency problems.

4.2.2 State ownership variables. State control is a variable measuring the percentage of votes controlled by the Russian state, in relation to total votes. Both direct and indirect control is taken into account. The 20 percent threshold of votes is required for a firm to be considered as state controlled in line with La Porta et al. (1999). An indirect state holding can occur through another listed firm, in which case this ultimate state control is added to the direct state holding. A similar control threshold has been used, for example, in Maury and Liljeblom (2009) on Russian data. We also employ a squared term of the state control variable to explore possible non-linearities in the state control-performance relation. The state control variable is used to test $H 1$. To further separate between legal majority power and non-majority holdings, we create two dummy variables, majority and minority, which take the value of one if the Russian state has control of 50 percent or more (Majority), or over 20 percent but less than 50 percent (Minority) of the votes, respectively, and otherwise they take the value zero[17]. We use 20 percent of the votes as the minimum for state control, since that level has been argued to be usually enough for exercising control of a firm (La Porta et al., 1999). The Russian state has a control position in 146 firm-year observations. Within the state-controlled firms, the Russian state has a majority position in 126 firm-years, and a minority in 20 observations.

Direct ownership is a dummy for cases when the state has control (over 20 percent of the votes) through direct ownership. The variable is included in a separate model as the explanatory state ownership variable, in order to test our $H 2$. We also use a dummy variable for indirect ownership through another firm in our model. Indirect state control may still give access to state resources but reduce the negative governance effects arising from direct 
IJOEM 15,2

state involvement (e.g. Okhmatovskiy, 2010). The Russian state has direct control in 74 firm-year observations, and indirect in 72 .

Regional ownership is a dummy for regional state ownership, and takes the value of one if a Russian regional authority has control over 20 percent of the votes in a firm, and the value of zero otherwise. We estimate a separate model using that variable as the explanatory state ownership variable, in order to test our $H 3$. We also include as a control variable a dummy for federal ownership. In our sample, Russian state ownership is of the federal form in 118 firm-years, and of the regional form in 14 cases (in all cases, owned by the Tatarstan region). In addition to these, we use a dummy for mixed ownership (federal and regional). For the dummy mixed ownership, we require that both levels have control of at least 20 percent of the votes. All state-controlled firms only belong to one of these three dummy categories. The regions which are involved in mixed ownership are St Petersburg (four observations), Sakha (five observations) and Moscow (five observations), in total 14 cases of mixed ownership.

Golden share is finally a dummy variable that takes the value of one for firms with golden shares, and zero otherwise. The data on golden shares have been retrieved manually from firms' annual reports. It is used to test our $H 4$. In addition to the state ownership variables, we include a test variable for the incremental effect of exercising the state control through golden shares. We expect that the golden shares variable has a positive coefficient, i.e. that such shares mitigate the negative effects of state ownership (i.e. the effect of the other state ownership variables included in the models).

4.2.3 Control variables. We will use different sets of control variables for the models for profitability, valuation, or efficiency, following what has typically been used for such models in the literature (e.g. Boardman and Vining, 1989). However, here we specify our complete set of controls. First, since the use of debt affects profitability and valuation, we need to include leverage, defined as total liabilities to total assets. Leverage is a natural control variable in all studies using ROE, ROA or ROS as a dependent variable, since returns on equity (and the risk as well) can be boosted by taking on more debt. The variable has been used as a control variable by, for example, Yu (2013), Dewenter and Malatesta (2001), Boubakri et al. (2008) and Vanteeva and Hickson (2016). Pöyry and Maury (2010) found that Russian state-owned firms as well as companies controlled by oligarchs have a higher leverage than other firms. This would indicate that strong owners have a better access to debt capital. They also found a negative relationship between profitability and leverage, which further motivates its inclusion as a control variable in our models.

Our main variable for firm size is lnSales defined as the natural logarithm of total sales, and it is used in the profitability and valuation models. In the sales/employees efficiency models, we use total assets (LnTotal assets) instead of sales as in Boardman and Vining (1989). Big companies have been found to be more profitable than small ones due to economies of scale (Lee, 2009). The sales variable has been used as a control variable in Dewenter and Malatesta (2001), Boardman and Vining (1989) and Boubakri et al. (2008).

We also include firm age (LnAge), defined as the natural logarithm of firm age, as a control variable in all models. The age variable is related to the tradeoffs among learning, new investments, and decline (e.g. Agarwal and Gort, 1996). In addition, Evans (1987) report lower growth (but also lower risk for bankruptcy) for older firms.

We also include sales growth in the valuation models, defined as the percentage change in annual sales from prior year (e.g. Black et al., 2006) winsorized at the 1st and 99th percentiles, respectively. This variable is a standard control in models using Tobin's $Q$ as a dependent variable, and distinguishes between value and growth firms that typically have different valuations.

In the valuation models, we also use the dummy variable dual listing for companies listed on more than one stock market. In total, 204 firm-year observations have a dual listing. 
Dual listings can be a sign of improved corporate governance and may therefore be related especially to higher firm value (Doidge, 2004; Maury and Liljeblom, 2009).

We include as control variables also several dummy variables. The following industry classifications are used: energy, steel/minerals/mines, oil and gas, telecommunications, retail, shipping and other (the dummy for other is the one excluded from the models to avoid multicollinearity). In a separate specification with interaction variables, we also employ a dummy variable for extractive industries which equals one for oil, gas, minerals, steel, mining and energy sectors, and zero otherwise (for non-extractive sectors).

\section{Results}

\subsection{Descriptive statistics}

Table II shows the sample breakdown by firm-years in different sectors and state ownership categories. As the table shows, the Russian listed firms in our sample have a state owner in approximately 40 percent of the cases. State ownership is mostly of the majority control type (about 85 percent), and mostly at the federal level (about 80 percent). The regions have a control position in about 20 percent of the firm-years, of which in about half of the cases jointly with federal control. The largest sector represented is energy (about 30 percent), and the Russian state is in control in about 75 percent of the energy firms. Within retail on the other hand, there are no state-controlled firms.

Table III reports the age of the firms in the sample. About 33 percent of the firm-years represent older companies that are founded in 1983 or before. The privately and state-owned companies are about equally old. The firms with minority and/or regional ownership, as well as the companies with golden shares are on average older firms.

Table IV reports descriptive statistics for our performance variables, while Table V shows statistics for the control variables. As Table IV shows, the average Tobin's $Q$ of 0.55 is low compared to developed markets and partly reflects the Russian crisis after the financial crisis and during the sanctions against the Russian economy. Tobin's $Q$ is lowest for indirectly state-controlled firms, while it is highest for privately controlled firms and

\begin{tabular}{|c|c|c|c|c|c|c|c|c|}
\hline & Energy & $\begin{array}{l}\text { Steel, minerals } \\
\text { and mines }\end{array}$ & Oil and gas & Telecom & Retail & Shipping & Other & Total \\
\hline Private ownership & 25 & 70 & 29 & 20 & 20 & 5 & 45 & 214 \\
\hline State control & 80 & 10 & 21 & 10 & 0 & 10 & 15 & 146 \\
\hline Majority & 80 & 10 & 16 & 10 & 0 & 5 & 5 & 126 \\
\hline Minority & 0 & 0 & 5 & 0 & 0 & 5 & 10 & 20 \\
\hline Federal ownership & 71 & 5 & 16 & 5 & 0 & 10 & 11 & 118 \\
\hline Regional ownership & 0 & 0 & 5 & 5 & 0 & 0 & 4 & 14 \\
\hline Mixed ownership & 9 & 5 & 0 & 0 & 0 & 0 & 0 & 14 \\
\hline Direct ownership & 14 & 10 & 21 & 10 & 0 & 10 & 9 & 74 \\
\hline Indirect ownership & 66 & 0 & 0 & 0 & 0 & 0 & 6 & 72 \\
\hline Golden share & 0 & 0 & 5 & 0 & 0 & 5 & 10 & 20 \\
\hline All firm-years & 105 & 80 & 50 & 30 & 20 & 15 & 60 & 360 \\
\hline
\end{tabular}

Notes: The table shows the sample breakdown by form of state ownership and sector. State control means that the Russian state controls at least 20 percent of the share capital. Majority means that the Russian state owns 50 percent or more of the votes. Minority means that the Russian state owns over 20 percent but less than 50 percent of the votes. Federal and regional ownership indicate whether the ownership in on federal or regional level, respectively. Mixed ownership means that both the federal and the regional levels have control for at least 20 percent of the votes. Direct/indirect ownership refers the whether the ownership is direct or through pyramidal ownership. Golden share lists the firm-years when the Russian state owns a so-called Golden Share in the firm. The time period is 2011-2015 (360 firm-years)
Complex state ownership 
IJOEM

15,2

Table III.
Sample breakdown by firm age

202
Founded on average

Old $(\%)$

Total sample

Private ownership

1977

1977

1977

1984

Majority

Minority

Federal ownership

Regional ownership

Mixed ownership

Direct ownership

Indirect ownership

Golden share
1918

1985

1972

1923

1973

1982

1943
33

35

31

21

91

23

64

64

34

28

75

Notes: The table reports the number of firm-years (cases when the firm has been in existence at least 10 years before the privatization, i.e. in existence in 1983 or before), in the different state ownership categories. For ownership category definitions, see Table II

firms with golden shares. Profitability is highest on average among golden share companies, regionally owned firms, and privately controlled firms. Table V shows that the state-controlled firms are typically much bigger than the privately controlled, both in terms of sales, number of employees and total assets. Their leverage is somewhat lower than in private firms. Sales growth in rubles is in general very high, partly because of the declining exchange rate during the time period. A more detailed analysis of sectors (not reported here) shows that the most profitable sectors have been oil and gas,

\begin{tabular}{|c|c|c|c|c|c|}
\hline & $\mathrm{ROA}(\%)$ & ROE (\%) & ROS $(\%)$ & Tobin's $Q$ & Sales/Employee \\
\hline Total (mean) & 3.72 & 6.81 & 15.03 & 0.55 & 8.18 \\
\hline SD & 9.60 & 31.56 & 12.77 & 0.61 & 8.34 \\
\hline \multirow[t]{2}{*}{ Private ownership } & 4.19 & 7.65 & 16.05 & 0.71 & 9.24 \\
\hline & 10.55 & 38.28 & 12.99 & 0.71 & 9.98 \\
\hline \multirow[t]{2}{*}{ State control } & 3.02 & 5.57 & 13.54 & 0.32 & 6.62 \\
\hline & 7.98 & 17.62 & 12.33 & 0.29 & 4.63 \\
\hline \multirow[t]{2}{*}{ Majority } & 2.93 & 6.43 & 12.64 & 0.28 & 6.85 \\
\hline & 5.39 & 10.04 & 10.60 & 0.27 & 4.90 \\
\hline \multirow[t]{2}{*}{ Minority } & 3.61 & 0.21 & 19.24 & 0.52 & 5.13 \\
\hline & 17.16 & 40.88 & 19.52 & 0.30 & 1.80 \\
\hline \multirow[t]{2}{*}{ Federal ownership } & 2.40 & 4.94 & 12.33 & 0.28 & 6.51 \\
\hline & 7.90 & 18.47 & 12.30 & 0.27 & 4.51 \\
\hline \multirow[t]{2}{*}{ Regional ownership } & 8.54 & 10.87 & 16.41 & 0.53 & 4.59 \\
\hline & 9.35 & 14.78 & 6.85 & 0.23 & 2.69 \\
\hline \multirow[t]{2}{*}{ Mixed ownership } & 2.75 & 5.63 & 20.86 & 0.39 & 9.55 \\
\hline & 4.92 & 11.96 & 14.37 & 0.42 & 5.96 \\
\hline \multirow[t]{2}{*}{ Direct ownership } & 4.97 & 6.98 & 20.06 & 0.46 & 6.90 \\
\hline & 7.17 & 21.21 & 11.99 & 0.30 & 4.73 \\
\hline \multirow[t]{2}{*}{ Indirect ownership } & 1.02 & 4.13 & 6.84 & 0.16 & 6.33 \\
\hline & 8.32 & 12.95 & 8.54 & 0.17 & 4.55 \\
\hline \multirow[t]{2}{*}{ Golden share } & 10.82 & 7.16 & 27.75 & 1.25 & 6.55 \\
\hline & 9.36 & 36.91 & 13.26 & 1.28 & 1.74 \\
\hline
\end{tabular}

Table IV.

Descriptive statistics for performance measures
Notes: The table reports descriptive statistics (averages and standard deviations) for the following performance measures: return on assets (ROA), return-on-equity (ROE), return over total sales (ROS), Tobin's $Q$ and total sales divided by the number of employees (Sales/Employee). We report these descriptive statistics both for all firm-years (Total), as well as for different state ownership categories. For ownership category definitions, see Table II 


\begin{tabular}{|c|c|c|c|c|c|c|}
\hline & TS & Employees & TA & Leverage $(\%)$ & $\mathrm{SG}(\%)$ & $\begin{array}{l}\text { complex state } \\
\text { ownershin }\end{array}$ \\
\hline \multirow{4}{*}{$\begin{array}{l}\text { Total (mean) } \\
\text { SD } \\
\text { Private ownership }\end{array}$} & 377.96 & 43.66 & 664.74 & 30.44 & 14.80 & \\
\hline & 925.54 & 67.12 & 1888.99 & 19.69 & 39.20 & \\
\hline & 295.07 & 33.74 & 395.71 & 31.75 & 13.64 & \\
\hline & 694.99 & 42.62 & 745.49 & 21.87 & 19.15 & \\
\hline \multirow{2}{*}{ State control } & 499.45 & 58.20 & 1059.00 & 28.51 & 16.48 & \\
\hline & 1177.43 & 90.16 & 2784.75 & 15.84 & 57.11 & 203 \\
\hline \multirow[t]{2}{*}{ Majority } & 545.06 & 60.67 & 1185.33 & 28.06 & 17.56 & \\
\hline & 1259.96 & 96.10 & 2977.96 & 13.04 & 60.90 & \\
\hline \multirow[t]{2}{*}{ Minority } & 212.14 & 42.69 & 263.11 & 31.40 & 9.66 & \\
\hline & 187.57 & 31.26 & 255.45 & 28.04 & 20.83 & \\
\hline \multirow[t]{2}{*}{ Federal ownership } & 575.83 & 65.71 & 1245.84 & 30.52 & 18.62 & \\
\hline & 1296.35 & 98.11 & 3068.24 & 15.53 & 63.17 & \\
\hline \multirow{2}{*}{ Regional ownership } & 223.91 & 35.61 & 276.39 & 12.37 & 5.36 & \\
\hline & 230.63 & 31.83 & 323.57 & 7.95 & 13.35 & \\
\hline \multirow[t]{2}{*}{ Mixed ownership } & 131.22 & 17.52 & 266.84 & 27.78 & 9.60 & \\
\hline & 66.36 & 13.42 & 112.28 & 15.72 & 7.45 & \\
\hline \multirow[t]{2}{*}{ Direct ownership } & 872.46 & 94.77 & 1923.41 & 28.90 & 25.58 & \\
\hline & 1563.84 & 114.36 & 3719.26 & 17.47 & 77.70 & \\
\hline \multirow[t]{2}{*}{ Indirect ownership } & 116.09 & 20.62 & 170.58 & 28.12 & 7.14 & \\
\hline & 150.81 & 18.10 & 188.69 & 14.08 & 16.69 & \\
\hline \multirow[t]{2}{*}{ Golden share } & 180.36 & 27.64 & 243.33 & 25.07 & 19.93 & \\
\hline & 201.90 & 29.39 & 267.60 & 27.47 & 22.83 & \\
\hline \multicolumn{6}{|c|}{$\begin{array}{l}\text { Notes: The table reports descriptive statistics (averages and standard deviations) for the following control } \\
\text { variables: TS defined as total sales in billion rubles, the number of employees in thousands (Employees), total } \\
\text { assets in billion rubles (TA), sales growth (SG) and leverage (Leverage). We report these descriptive statistics } \\
\text { for all firm-years (Total), as well as for different state ownership categories. For ownership category } \\
\text { definitions, see Table II }\end{array}$} & $\begin{array}{r}\text { Table V. } \\
\text { Descriptive } \\
\text { statistics for selected } \\
\text { variables by state } \\
\text { ownership type }\end{array}$ \\
\hline
\end{tabular}

telecommunications, retail and other firms. The highest Tobin's $Q \mathrm{~s}$ are found for retail, telecommunications, steel, minerals and mines, and other sectors. An analysis of listings (i.e. second listing or not) shows that dual listed firms in general have better profitability, valuation and efficiency. This is in line with prior studies (Benos and Weisbach, 2004; Maury and Liljeblom, 2009). Such companies are also bigger and more levered; the latter pattern is probably due to better access to credit markets.

An analysis of correlations and also based on variance inflation factors indicates that multicollinearity should not pose problems. The biggest correlations appear between different state control variables, which anyway are not simultaneously included in the analysis.

\subsection{Results from panel model estimations}

Table VI shows the relation between forms of state ownership and firm performance. Panel A shows that state control is negatively related to firm valuation measured by Tobin's $Q$. The majority and minority state ownership dummy variables are both negative as compared with firms without controlling state ownership, but the coefficient for minority ownership $(-1.16)$ is larger and more significant than the majority dummy $(-0.23)$. Our results depart from those in Boubakri et al. (2018) who find that minority government ownership is associated with higher firm valuation. To further explore the non-linearity of state ownership, we add a squared term for state control. It is positive and statistically significant indicating a convex function, and that the inflection point is at around 50 percent ownership. Thus, we find that state control is associated with lower valuations in general, the effect is less negative for higher control levels compared to other owner types, and the effect of increases in fractional state ownership over 50 percent becomes positive. 
\begin{tabular}{l} 
IJOEM \\
15,2 \\
$\mathbf{2 0 4}$ \\
\hline
\end{tabular}

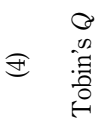

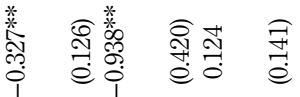

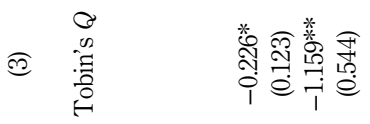

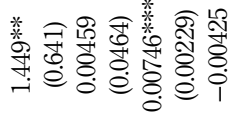

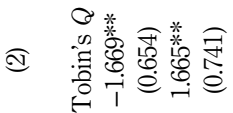

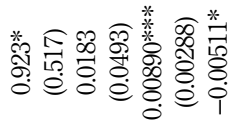

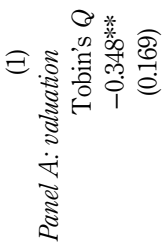

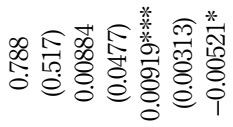

Table VI.

State control firm performance

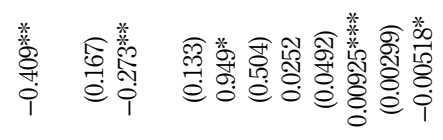

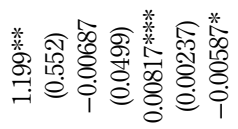

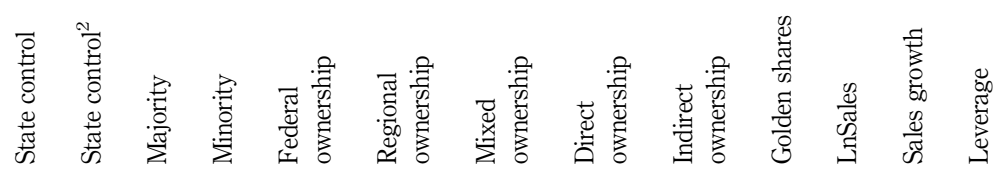




$$
\text { aํ }
$$

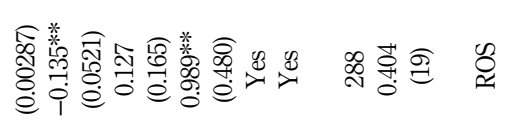

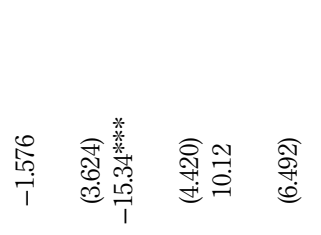

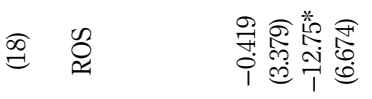

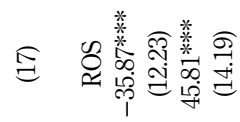

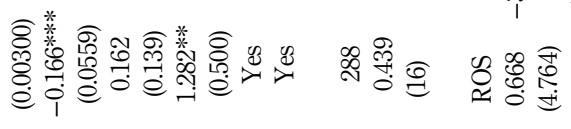

$$
\text { 要罯 }
$$

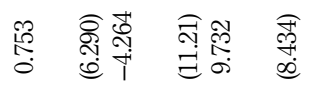

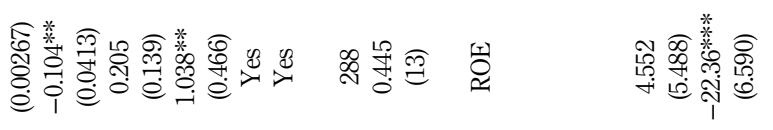

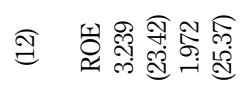

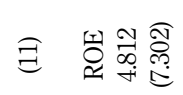

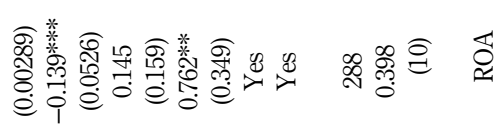

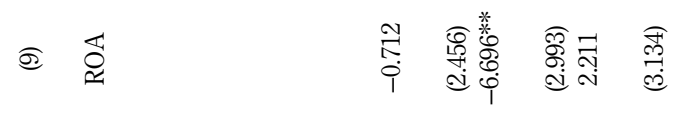

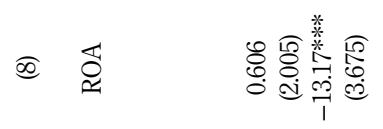

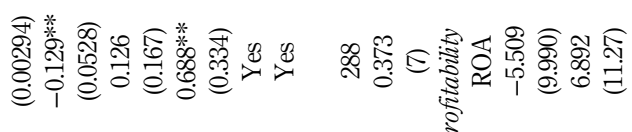

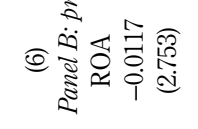

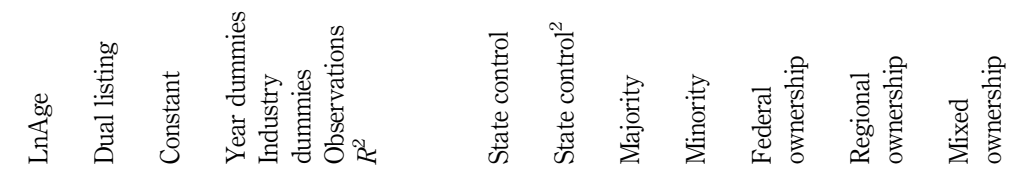




\begin{tabular}{l} 
IJOEM \\
15,2 \\
$\mathbf{2 0 6}$ \\
\hline
\end{tabular}

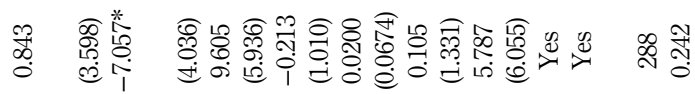

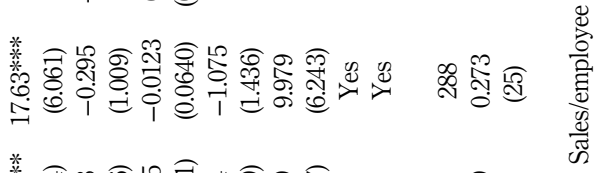

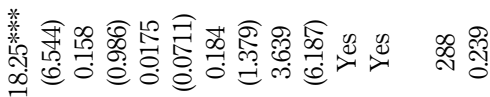

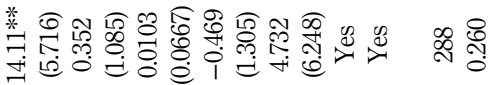

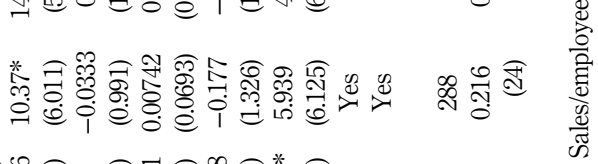

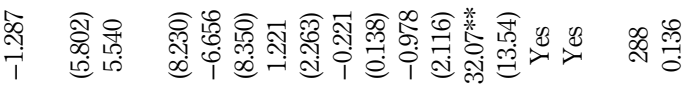

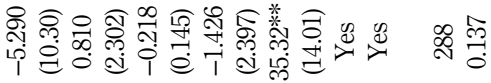

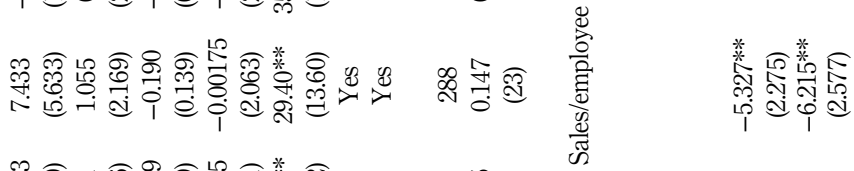

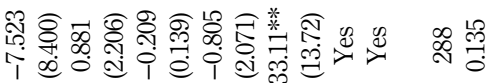

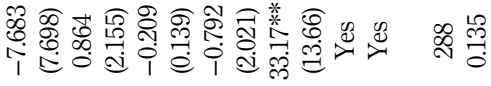

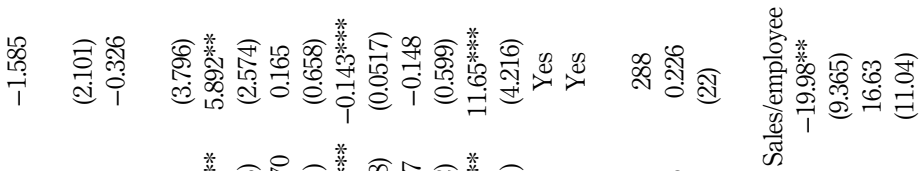

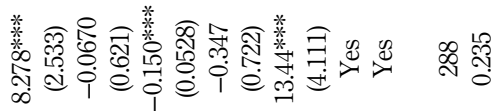

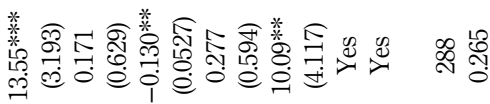

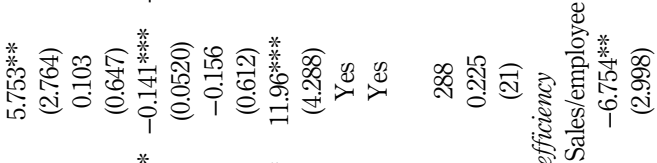

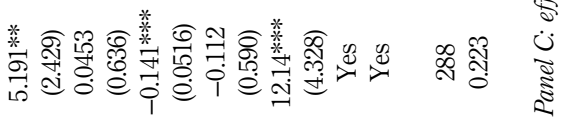

Table VI.

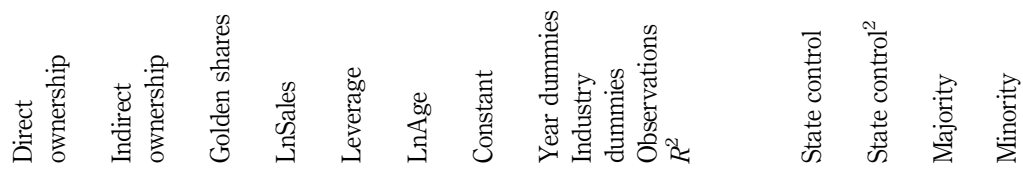




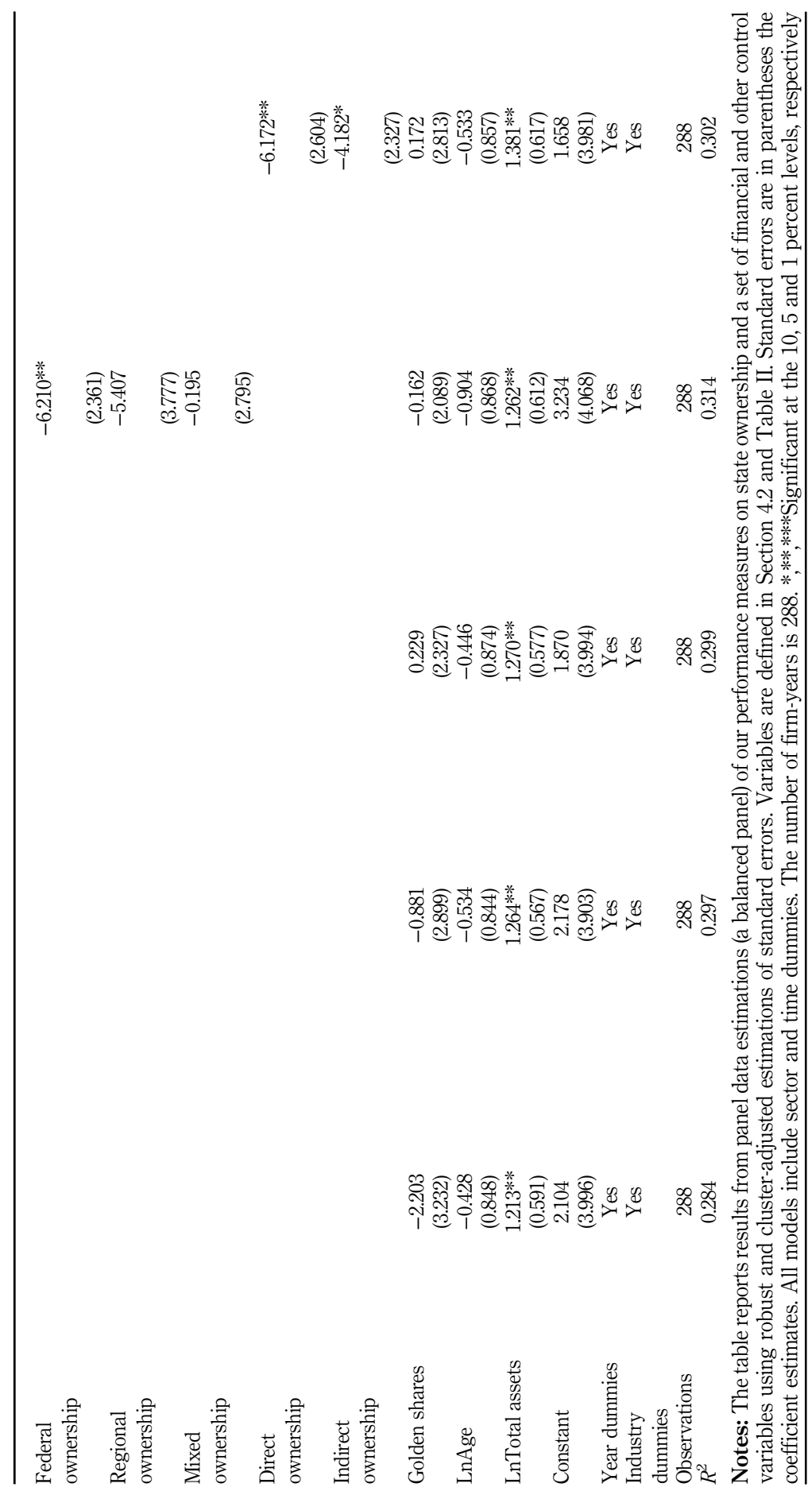

Complex state ownership

207

S

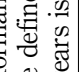
光完 .్ㅜㅇ

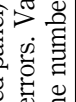

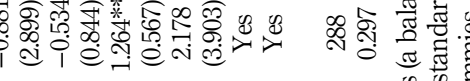
. . 范

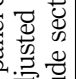
\%ิส 
IJOEM

15,2

208

Our results are in line with $H 1$ that the costs of state ownership conflicts exceed the rents in terms of market perceptions of performance at least for lower levels of control.

Panel B of Table VI shows the relation between the level of state control and profitability. While state control is generally not statistically significantly related to profitability, the coefficient for minority control is negative statistically significant across profitability measures. The results for minority ownership are in line with $H 1$ (that costs of state ownership conflicts exceed the rents). The majority dummy is not statistically significant in the profitability regression. When we include a squared term for state control, we obtain a positive although mostly statistically insignificant coefficient. In sum, minority state control has a significantly negative effect on profitability as compared to firms with private owners.

Table VI also shows that regional state control has a significantly negative effect on Tobin's $Q$ and profitability measures except for ROE, while federal state control is insignificantly related to profitability but significantly negatively related to Tobin's $Q$. However, the coefficient for federal control is much lower than for regional control in valuation models. Mixed state control is positively but statistically insignificantly related to profitability and valuation. Hence, we obtain support for $H 3$, which states that regional ownership is negatively related to performance. In addition, the results for direct vs indirect state control show that both direct and indirect state control are significantly negatively related to Tobin's $Q$, and also that the coefficient is larger for direct state control, which gives some support to H2. In terms of profitability, only indirect state control is negatively related to ROS. Taken together, the market seems to penalize regional as well as both direct and indirect ownership, while only regional state control seems to be associated with poorer profitability.

In Table VI, the golden share dummy is generally positively related to Tobin's $Q$ and profitability in support of $H 4$, which states that golden shares should have a non-negative effect on profitability, efficiency and value because such control does not typically increase conflicts between owner groups while it may enable non-market rents for the firm.

Panel C of Table VI shows the relation between forms of state control and the sales/ employee efficiency ratio. State control is statistically significantly negatively related to sales/employees. A significantly negative relation is also found for majority and minority state holdings. Federal state control is significantly negatively related to sales per employee, while regional and mixed ownership are statistically insignificant. Both direct and indirect state control is negatively and statistically significantly related to sales/employee. Golden shares are insignificantly related to the sales/employee ratio. Thus, state control is generally significantly negatively related to the efficiency ratio sales/employee, which further supports the argument of inefficiency associated with state ownership arising from employment prioritization over economic goals.

In Table VII, we explore how the level of competition affects the state ownership-performance relation. We interact extractive industries (oil, gas, minerals, steel, mining, minerals and energy sectors), which arguably are less competitive, with our state control variables. The results show that there is a statistically significant difference in the state ownership/profitability relation between extractive industries and non-extractive industries, with a higher profitability in extractive industries. In terms of profitability, we obtain support for $H 5$ stating that lower competition will improve the performance of state-controlled firms. However, there is no systematic difference in valuations between extractive and non-extractive industry categories. State control is generally not significantly different for the sales/employee efficiency ratio in extractive and other industries. However, when competition is accounted for, regional ownership (instead of federal as in Table VI) has a statistically significant negative relationship to sales/employees. Overall, lower competition in the extractive industries appears to drive significantly higher profitability in state-controlled firms despite the potentially high agency problems associated with state control. 

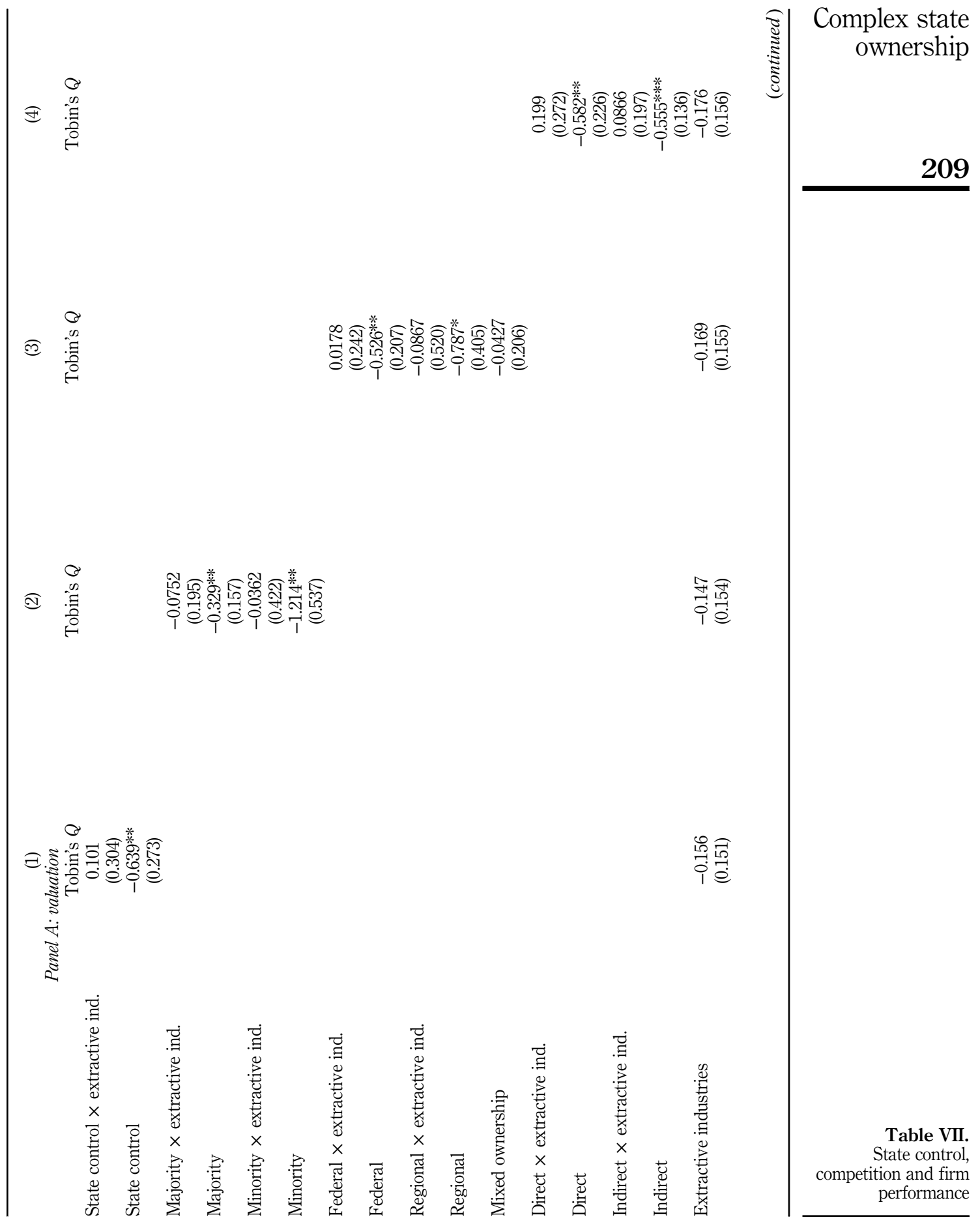


\begin{tabular}{l} 
IJOEM \\
15,2 \\
$\mathbf{2 1 0}$ \\
\hline
\end{tabular}

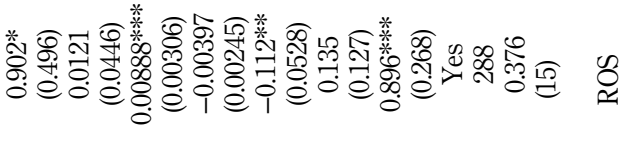

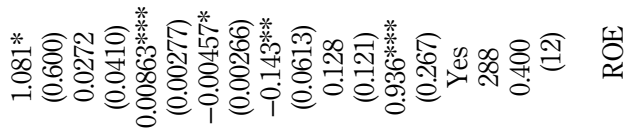

$$
\text { 凷 됭 }
$$

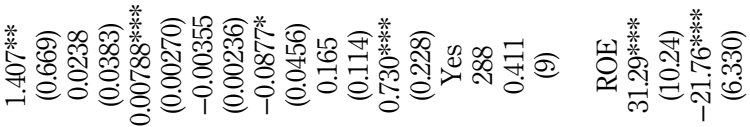

$$
\begin{aligned}
& \text { ब } \\
& \in \mathbb{8}
\end{aligned}
$$

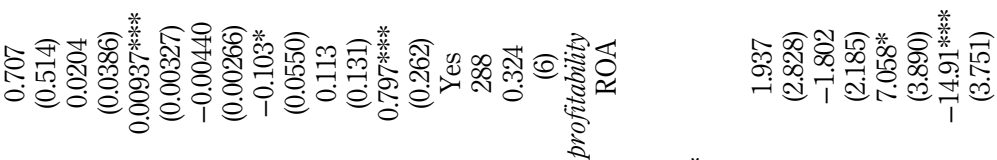

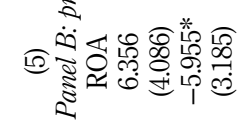

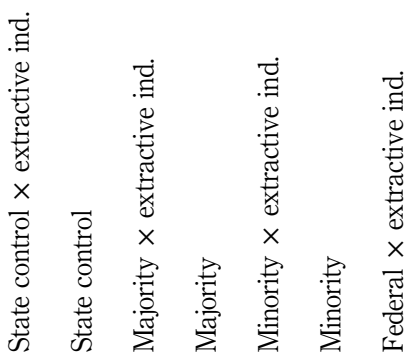

Table VII.

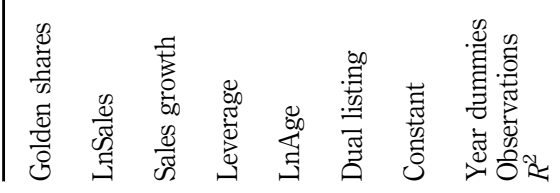




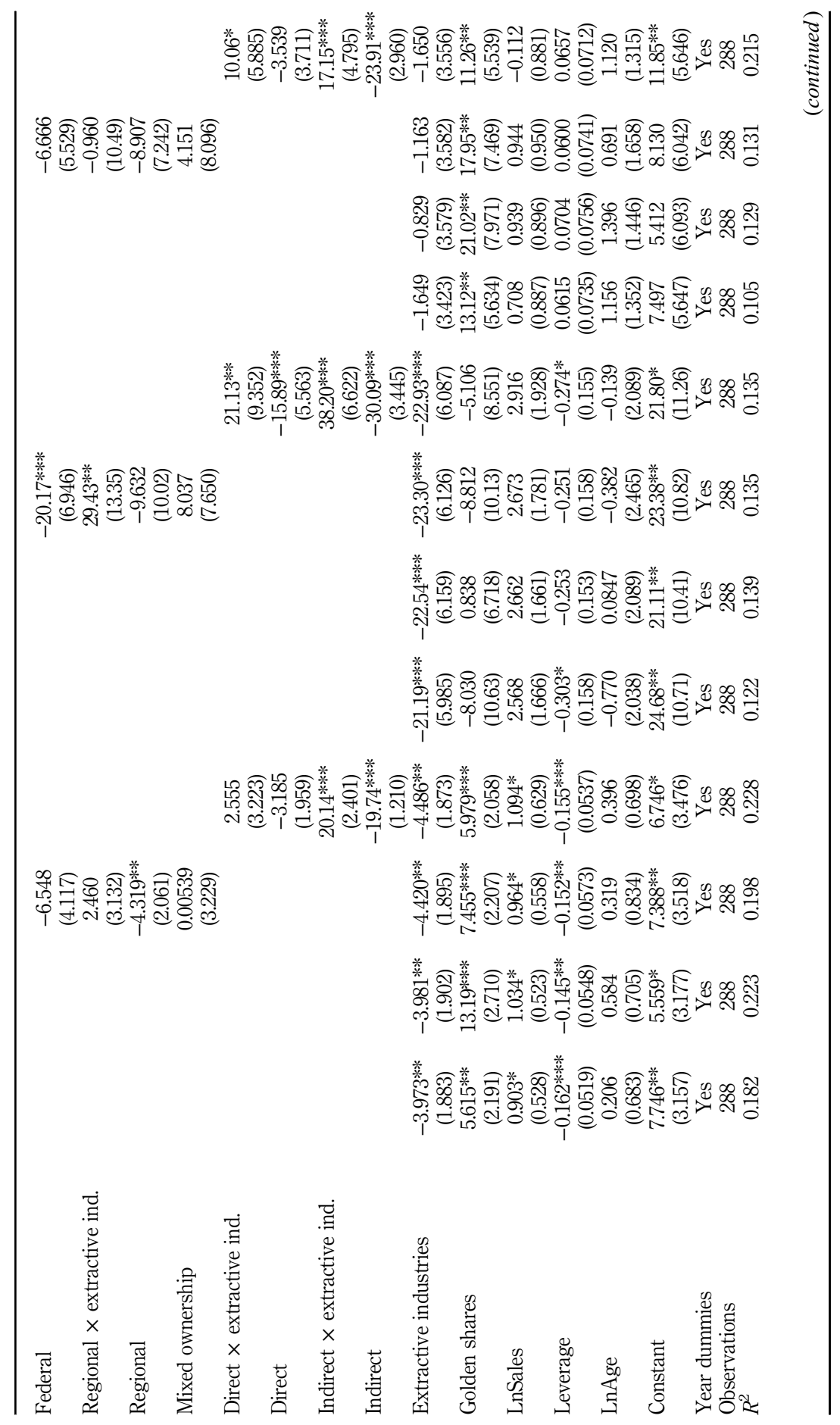

Complex state ownership

211

Table VII. 
\begin{tabular}{l} 
IJOEM \\
15,2 \\
$\mathbf{2 1 2}$ \\
\hline
\end{tabular}

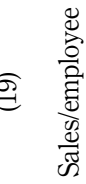

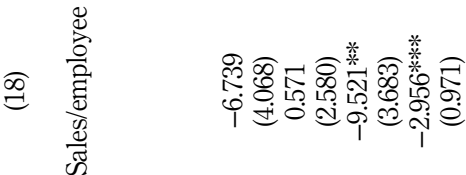

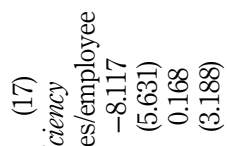

递

छั

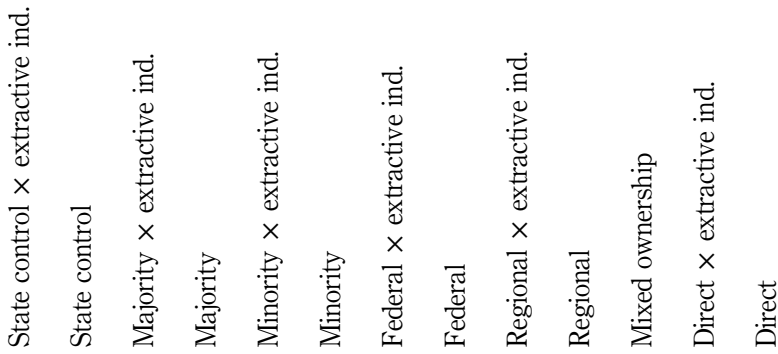

Table VII.

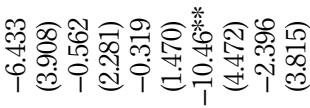

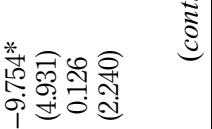

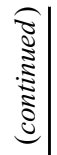

$$
\begin{aligned}
& \text { है } \\
& \text {. }
\end{aligned}
$$




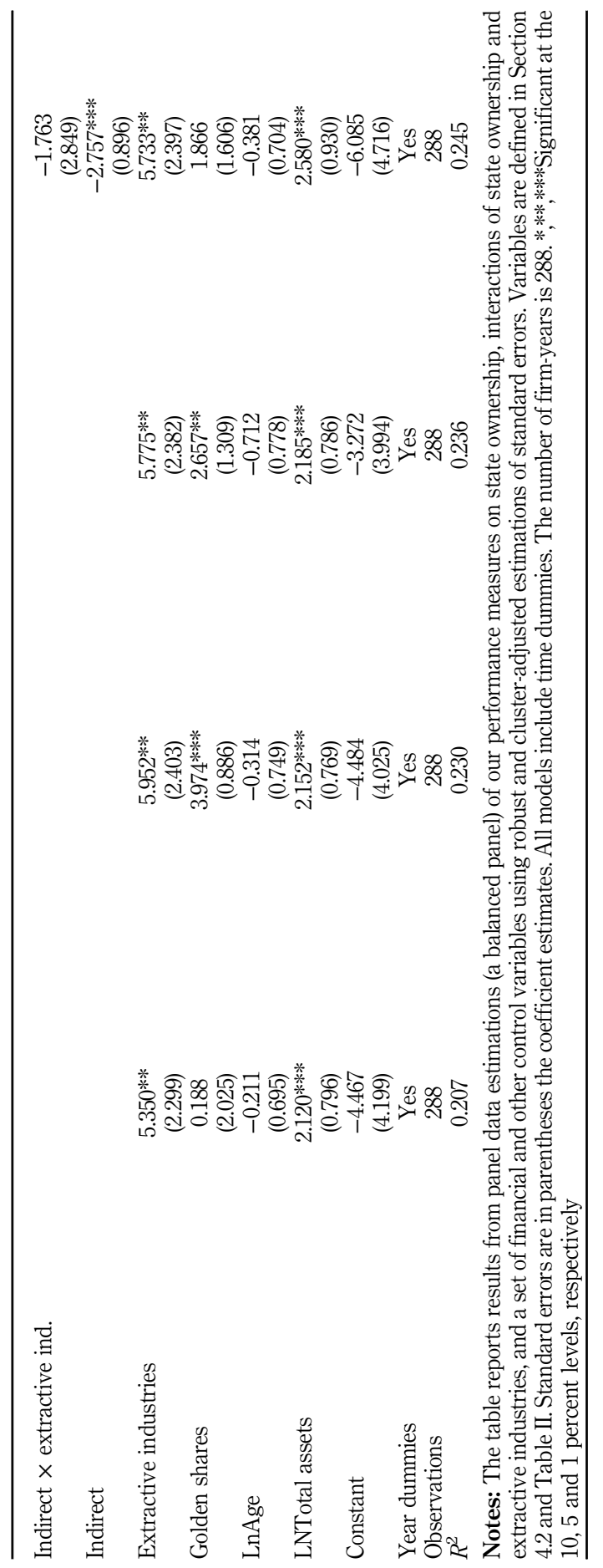

Complex state ownership

213

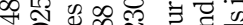

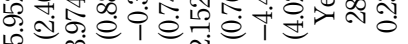

बे

, bo

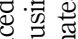

츤

제

용

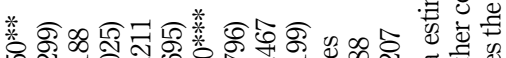
ป⿻ 它 .풍 ते 
IJOEM

15,2

214
Of the control variables in Table VI, leverage is significantly negatively related to $R O A$ and Tobin's $Q$. In the model using Tobin's $Q$, the control variables sales growth (positive) and firm age (negative) are statistically significant, indicating higher valuations younger and growing companies. Dual listing has a positive but statistically insignificant effect in valuation models. The size variable LnTotal assets is positive and statistically significant in the sales/employees model, while the LnSales variable is typically statistically insignificant in the Tobin's $Q$ and profitability models.

\subsection{Robustness tests}

We performed a number of robustness tests. First, we estimated the models using winsorized data for the dependent variables at the 5 percent/95 percent levels. Second, we also estimated models with random effects and again using robust and clustered standard errors. The results are robust to these modifications. Third, to control for endogeneity from profitability to state ownership we report the main results using lagged independent variables. For robustness, we also estimated the models using dependent and independent variables measured in the same year, and the results are very similar to those reported. Finally, we estimated separate models for the time period before the sanctions against Russia (the years 2011-2013), and the period of sanctions (2014-2015). Again, results are robust. State control is significantly negative related to valuation in both sub-periods. Minority ownership is the form of state involvement that more severely affects performance both before and after the sanctions. Golden share obtains some positive significance relating to performance (especially ROA and Tobin's $Q$ ) during both periods. Direct ownership exhibits consistently more often a significant negative relation to performance as compared to indirect ownership, and finally regional ownership exhibits a significant negative relationship to most performance variables during both sub-periods.

\section{Discussion and summary}

\subsection{Discussion of findings and implications}

In this section, we tie together the results from Section 5. It is of interest to study the performance effects of Russian state ownership in listed companies for many reasons. First, since these are listed firms, meaning that in no case is the Russian state the sole owner but there are other shareholders also investing in these firms, it is of importance that such shareholders understand the conditions under which the firm operates, including those related to state ownership. Our study helps shed light on the potential consequences that state ownership may have, and how it can vary depending on the size and form of such ownership. If the state, for example, has other goals than pure financial performance, it is of importance that the owners share these goals or at least are aware of them when investing. Otherwise such other shareholders may face disappointments if they expect the same performance as from firms without state ownership. Second, our study also sheds light on how the performance varies depending on the form of state ownership, which may also be of interest for the Russian state itself, when tailoring its ownership policy (unless of course already known by the state). For example, the effect of golden shares may be of interest or whether regional ownership differs from federal, a difference which may either be due to differences in goals or may be due to different levels of agency problems associated with the different forms.

A number of patterns regarding the performance effects of state ownership emerge from our findings and relate to the type, form, size and relative size of ownership. First, our results show that firms controlled by regional government perform worse than federally controlled ones. This may either be due to differences in goals such as social concerns weighing more for the regional owners, or due to differences in the magnitude of agency problems. The latter alternative is in line with prior literature such as Blanchard and Shleifer (2001), who point at the challenges for the Russian state to control regional governors and the corruption 
associated with regional control. It is also in line with a potentially higher likelihood of self-dealing by regional governors due to their lower likelihood of being prosecuted, observed for Chinese firms by Cheung et al. (2010), and the conflicts between regional and federal powers in Russia as well as unclear regional governance practices (Nelson and Kuzes, 2002). The result in Table VII indicate that firms with regional ownership employ more than privately controlled firms (significant for non-extractive industries), point at different goals at least being part of the explanation for performance differences.

While we find that the general effect of state control on performance is negative, our results also indicate that the size of state holdings matters, and in particular that the performance of majority ownership is slightly higher than for minority holdings by the state. Previous research indicates that governments often aim at having majority ownership in monopolies and strategically important firms (Shleifer, 1998). Muravyev (2002) finds that strategic state ownership outperforms non-strategic state control. If majority ownership by the state is associated with higher entry barriers, one would expect majority ownership to outperform minority shareholdings. Another interpretation of majority holdings by the state is that it is associated with stronger political connections that can benefit the firm. Relatedly, $\mathrm{Yu}$ (2013) find that majority state-owned firms outperform minority controlled ones in China, and argues that large state holdings get more preferential treatment through their political connections than firms with smaller state influence. However, Boubakri et al. (2018) find that non-majority government ownership is associated with higher firm valuation as compared to non-government owned firms in East Asia. Our result for the extractive industries support the first explanation related to entry barriers.

Our results show that indirect state ownership performs better than direct ownership in terms of valuations and efficiency but not profitability. In his study of Russian banks, Okhmatovskiy (2010) finds that indirect state ownership outperforms direct ownership, and he argues that indirect state ownership can give a part of the benefits of political influence with a lower cost than in the case of direct ownership which typically means that the state takes a significant governance role in the firm. Such a signaling effect may give rise to the higher valuation we find to be associated with indirect state ownership.

The golden shares used by the Russian state may be considered a form of passive state control of firms. While a blockholding by the state (such as a minority stake) may give rise to incentives by other large blockholders to expropriate the state, the presence of golden shares (that are unrelated to cash flows) appear to be free from such expropriation (see also Muravyev, 2002). Our results, while keeping the small data sample in mind, are consistent with the idea that golden shares are not associated with expropriation by or of the state, but are rather associated with higher valuations as well as higher return on assets and sales, and thus possibly providing the some strategic benefits (rents) to the firm.

In terms of the role of competition on the state ownership-performance relation, we find state ownership is associated with significantly higher profitability in extractive industries than in non-extractive industries. Our results indicate that lower competition will improve the profitability of state-controlled firms. We also find that the relation between indirect state ownership and profitability is significantly different between extractive and non-extractive industries. Perhaps more importantly, there is no systematic difference in valuations between extractive and non-extractive industries. Thus, the higher profitability does not translate into higher valuations consistent with the view that minority shareholders may suffer from weak corporate governance in state-controlled firms. We conclude that the nature of the industry competition is an important performance determinant of various forms of state involvement in publicly traded firms.

The starting point for discussing policy implications is the goal of the possible governance reform needed. One feature of the Russian stock market is the high ownership concentration (e.g. Pöyry and Maury, 2010). The high concentration of control also means 
IJOEM

15,2

216

that an important agency conflict is the one between controlling shareholders and outside shareholders that should be the focus of policy reform. The goal of the legal reform should then be to improve the position of outside shareholders by increasing the cost of self-dealing (e.g. Djankov et al., 2008). According to Armour et al. (2009), this can be done through a regulatory strategy constraining agents (such as controlling shareholders and managers) and through a governance strategy empowering principals (such as outside shareholders). Our results suggest that the consequences of state ownership in the form of direct, regional, and minority stakes could be improved by principal empowering (governance strategy) and agent/insider constraining (regulatory strategy) (for details on legal strategies, see Armour et al., 2009). Thus, regional state ownership could be better monitored through a more effective enforcement strategy that would make self-dealing by regional governors more costly. Direct and minority state blockholdings and their contribution to performance could be enhanced with the same agent constraining and principal empowering strategies, with an emphasis on protecting outside investors.

\subsection{Summary and conclusions}

We contribute to the literature on the performance effects of state ownership by studying a multitude of forms of governmental ownership in Russia during 2011-2015. In the previous literature, there is a gap regarding the performance effects of various forms of government control in listed firms. The purpose of this study is to fill this gap by jointly exploring the relative influence of forms of state ownership including majority and minority ownership, golden shares, direct or indirect ownership, and federal, regional or mixed ownership. We use agency theory and prior studies to generate hypotheses concerning the potential benefits/harmfulness of state ownership. More specifically, we hypothesize that the negative effects of state control may outweigh the potential positive ones, and more so for direct and regional ownership, whereas control through golden shares (due to their lack of ownership rights) may be a less harmful way. We also hypothesize that state control can be associated with higher profits due to monopolistic rents they enjoy in certain strategic sectors.

Our data set is for 72 large listed Russian firms for the years 2011-2015, and we use several measures for firm performance: a market valuation measure (Tobin's Q), three profitability measures (ROA, ROE and return on sales) and an efficiency measure (sales per employee). The performance consequences of state ownership are found to differ between various forms of state ownership. State control in itself already exhibits a negative relationship with performance, but when split into majority or minority ownership, we find that the variable minority ownership seems to be the main carrier of these effects. For regional and federal ownership, we find that both ownership forms are significantly associated with some negative effects, but that the size of the coefficient estimates and their significance levels are typically higher for regional ownership. Our results for direct vs indirect ownership are more inconclusive, although we find a significant negative relationship between direct ownership and sales per employee and valuation. Finally, we find evidence supporting our hypothesis that ownership through golden shares can mitigate the otherwise negative effects of state ownership. An interesting feature is the negative relationship often encountered between the state control variables and sales per employment, suggesting (together with the negative relationships to profitability variables) that state-controlled firms tend to employ beyond what is economically optimal. In addition, in extractive industries the relation between state ownership and profitability becomes positive, which reflects the absence of competition. This paper enhances our understating of the relations among agency problems, competition, and forms of state ownership, and it is of practical interest for investors on markets with state-controlled firms such as on the Russian market.

Further research could address the renationalization of firms during the 2000s. While questions including the rationale behind the nationalizations have been addressed (see, Chernykh, 2011), the performance consequences from increases in state ownership in 
Russian firms could be further investigated. Furthermore, Bradshaw et al. (2016) have shown using Chinese firm data that state ownership tend to increase taxes paid. Future research could address the relation between state ownership and taxes paid by Russian

firms to further the understanding of the rationale behind state ownership.

\section{Notes}

1. For contrary views, i.e. that government ownership would not necessarily be less efficient than private ownership, see, e.g. Caves and Christensen (1980) and Kay and Thompson (1986).

2. See also, e.g. Abdallah and Ismail (2017) for positive effects from government ownership in firms in GCC (Gulf Cooperative Council) countries.

3. These results are also in line with other results for Asian markets such as Hess et al. and $\mathrm{Yu}$, who document a $U$-shaped relationship between government ownership and firm performance.

4. The Russian state needed to borrow money, and had placed parts of the shares in 12 big state-owned Russian firms as collaterals for the loans. When the loans could not be repaid before September 1996, the shares were sold out in an auction. For a discussion of the problems in the Russian privatization, see e.g. Black et al. (1999) and Treisman (2010).

5. Guriev and Rachinsky (2005) define a Russian oligarch as a businessman, who controls enough resources in order to execute strong influence on national politics. For the influence of Russian oligarchs on firm valuation, see Maury and Liljeblom (2009).

6. Our sample moreover excludes financial firms, i.e. a group of firms where the Russian state is a large owner.

7. The most common organizational form in Russia is a "Joint Stock Company" (JSC) in either a closed (CJSC) or open (OJSC) form. The difference between these forms is that in CJSCs, transfer of ownership to other parties is more restricted, it is harder to issue equity, and the financial reporting requirements are lower. CJSC is the more common form overall, but OJSC is more common for larger companies. About 60 percent of the big firms are OJSCs (Iwasaki, 2007). State-owned enterprises can also be in the form of a "Unitary Enterprise". These are owned at various state levels: federally owned (FGUP - Federal State Unitary Enterprise), regional level (GUP - State Unitary Enterprise) or municipal level (MUP - Municipal Unitary Enterprise). These companies are governed according to the law for state and municipally owned companies from 2002, and are always 100 percent state owned. Finally, there is a third type of state owned companies: "State Corporations". The first companies of this form were founded in 2007, by moving state property into the firms. The civil law governs badly these firms. The examples of such firms are Vneshekonombank and the energy company Rosatom (OECD, 2008).

8. Indirect evidence of agency problems in state and federal controlled firms on other markets has been reported, for example, by Cheung et al. (2010) for Chinese firms. They found that the amount of self-dealing was higher for regionally (rather than federally) controlled firms, and assumed this was due to the regional officers' lower risk of being accused for fraud.

9. There are large differences in the extent to which the rule of law in different countries mitigates these problems. The laws concerning minority protection are in a key role in mitigating agency problems of type two according to Djankov et al. (2008). They find that lower amounts of self-dealing are associated with higher market valuation of a firm. Studies show that ownership is more concentrated in countries with poorer minority protection (La Porta et al., 1998; Dyck and Zingales, 2004). Instead of causing agency problems, concentrated ownership may also mitigate them, since the problems between ownership and management (the agency problems of type one) may be reduced by concentrated ownership (Guriev and Rachinsky, 2005).

10. On the other hand, Estrin et al. (2009) report that wages in Russian state-owned companies typically have been lower than in the private sector.

11. State owned firms in Russia that are engaged in such production activities have typically not been properly compensated for by the state in Russia (Sprenger, 2010). 
IJOEM 15,2

12. In Faccio's (2006) global study of politically connected firms, Russia tops the list, with 86.75 percent of the Russian listed firms having a political connection.

13. In total, the Russian state has, according to their statistics, some form of ownership in 1,557 PJSCs.

14. See, e.g. Baltagi (2008) for a discussion. When the time dimension is short in relation to the number of firms, estimating a lot of extra parameters makes the FE model suffer from a large loss of degrees of freedom, and may aggravate the problem of multicollinearity among regressors. Moreover, the FE least squares estimator cannot estimate the effect of time-invariant variables. These time-invariant variables are wiped out (alternatively, one can say that such variables are spanned by the individual FE dummies). Since the ownership variables are our variables of interest, and they are pretty stationary over time on the firm level, this feature also talks against a full $\mathrm{FE}$ model.

15. These help to adjust for problems due to potential heterogeneity and also for outliers. A separate control test using winsorized dependent variables is reported among our robustness tests.

16. Also e.g. Okhmatovskiy (2010) and Yu (2013) used ROA, and Yu (2013) used also ROE.

17. Our two dummies represent a somewhat developed version of the state dummy used by, for example, Dewenter and Malatesta (2001).

\section{References}

Abdallah, A.A.-N. and Ismail, A.K. (2017), "Corporate governance practices, ownership structure, and corporate performance in the GCC countries", Journal of International Financial Markets, Institutions \& Money, Vol. 46 No. 1, pp. 98-115.

Abramov, A., Radygin, A. and Chernova, M. (2017), "State-owned enterprises in the Russian market: ownership structure and their role in the economy”, Russian, Journal of Economics, Vol. 3 No. 1, pp. 1-23.

Agarwal, R. and Gort, M. (1996), "The evolution of markets and entry, exit and survival of firms", Review of Economics and Statistics, Vol. 78 No. 3, pp. 489-498.

Ang, J.S. and Ding, D.K. (2006), "Government ownership and the performance of government-linked companies: the case of Singapore", Journal of Multinational Financial Management, Vol. 16 No. 1, pp. 64-88.

Armour, J., Hansmann, H. and Kraakman, R. (2009), "Agency problems, legal strategies and enforcement", The Anatomy of Corporate Law: A Comparative and Functional Approach, Chapter 2, Oxford University Press, New York, NY.

Baltagi, B.H. (2008), Econometric Analysis of Panel Data, 4th ed., John Wiley \& Sons, West Sussex.

Benos, E. and Weisbach, M.S. (2004), "Private benefits and cross-listings in the United States", Emerging Markets Review, Vol. 5 No. 2, pp. 217-240.

Black, B., Kraakman, R. and Tarassova, A. (1999), "Russian privatization and corporate governance: What went wrong?”, Stanford Law Review, Vol. 52 No. 6, pp. 1731-1808.

Black, B., Love, I. and Rachinsky, A. (2006), “Corporate governance indices and firms' market values: time series evidence from Russia”, Emerging Markets Review, Vol. 7 No. 4, pp. 361-379.

Blanchard, O. and Shleifer, A. (2001), "Federalism with and without political centralization: China versus Russia”, IMF Staff Papers, Vol. 48 No. S1, pp. 171-179.

Boardman, A.E. and Vining, A.R. (1989), "Ownership and performance in competitive environments: a comparison of the performance of private, mixed, and state-owned enterprises", Journal of Law and Economics, Vol. 32 No. 1, pp. 1-33.

Borisova, G., Brockman, P., Salas, J.M. and Zagorchev, A. (2012), "Government ownership and corporate governance: evidence from the EU”, Journal of Banking \& Finance, Vol. 36 No. 11, pp. 2917-2934.

Bortolotti, B. and Faccio, M. (2009), "Government control of privatized firms", Review of Financial Studies, Vol. 22 No. 8, pp. 2907-2939. 
Boubakri, N., Cosset, J.-C. and Guedhami, O. (2008), "From state to private ownership: issues from strategic industries", Journal of Banking \& Finance, Vol. 33 No. 2, pp. 367-379.

Boubakri, N., El Ghoul, S., Guedhami, O. and Megginson, W.L. (2018), "The market value of government ownership", Journal of Corporate Finance, Vol. 50 No. C, pp. 44-65.

Boycko, M., Shleifer, A. and Vishny, R. (1993), "Privatizing Russia”, Brookings Papers on Economic Activity, Vol. 1993 No. 2, pp. 139-192.

Bradshaw, M., Liao, G. and Ma, M. (2016), "Ownership structure and tax avoidance: evidence from agency costs of state ownership in China”, working paper, SSRN, available at: https://ssrn.com/ abstract $=2239837$ (accessed February 14, 2016).

Bruton, G.D., Peng, M.W., Ahlstrom, D., Stan, C. and Xu, K. (2015), "State-owned enterprises around the world as hybrid organizations", Academy of Management Perspectives, Vol. 29 No. 1, pp. 92-114.

Caves, D.W. and Christensen, L.R. (1980), "The relative efficiency of public and private firms in a competitive environment: the case of Canadian railroads", Journal of Political Economy, Vol. 88 No. 5, pp. 958-976.

Chernykh, L. (2008), "Ultimate ownership and control in Russia", Journal of Financial Economics, Vol. 88 No. 1, pp. 169-192.

Chernykh, L. (2011), "Profit or politics? Understanding renationalizations in Russia", Journal of Corporate Finance, Vol. 17 No. 5, pp. 1237-1253.

Cheung, Y.-L., Rau, P. and Stouraitis, A. (2010), "Helping hand or grabbing hand? Central vs. local government shareholders in Chinese listed firms", Review of Finance, Vol. 14 No. 4, pp. 669-694.

Deloitte (2015), "Corporate governance structures of public Russian companies”, Survey by the Deloitte CIS Centre for Corporate Governance, available at: www2.deloitte.com/content/dam/Deloitte/ru/ Documents/risk/corporate-governance-structures-survey-eng.pdf

Dewenter, K. and Malatesta, P.H. (2001), "State-owned and privately owned firms: an empirical analysis of profitability, leverage, and labor intensity", American Economic Review, Vol. 91 No. 1, pp. 320-334.

Djankov, S. (2015), "Russia's economy under Putin: from crony capitalism to state capitalism", PIIE Policy Brief Sept, Vol. 2015, pp. 15-18.

Djankov, S., La Porta, R., Lopez-de-Silanes, F. and Shleifer, A. (2008), "The law and economics of self-dealing", Journal of Financial Economics, Vol. 88 No. 3, pp. 430-465.

Doidge, C. (2004), "US cross-listings and the private benefits of control: evidence from dual-class firms", Journal of Financial Economics, Vol. 72 No. 3, pp. 519-553.

Dyck, A. and Zingales, L. (2004), "Private benefits of control: an international comparison", Journal of Finance, Vol. 59 No. 2, pp. 537-600.

Dyck, A., Volchkova, N. and Zingales, L. (2008), "The corporate governance role of the media: evidence from Russia”, Journal of Finance, Vol. 63 No. 3, pp. 1093-1135.

economy.gov.ru (2017a), "Management of public companies whose shares are in federal ownership, including the introduction of a positive corporate management experience, the development of the practice of recruiting professional directors", (in Russian language), available at: http://economy.gov.ru/minec/activity/sections/use/structure/ (accessed January 30, 2017).

economy.gov.ru (2017b), "Management of organizations with state participation”, (in Russian language), available at: http://economy.gov.ru/minec/activity/sections/use/gos/ (accessed January 30, 2017).

Estrin, S., Hanousek, J., Kocenda, E. and Svejnar, J. (2009), “The effects of privatization and ownership in transition economies", Journal of Economic Literature, Vol. 47 No. 3, pp. 699-728.

Evans, D. (1987), “Tests of alternative theories of firm growth”, Journal of Political Economy, Vol. 95 No. 4, pp. 657-674.

Faccio, M. (2006), "Politically connected firms", American Economic Review, Vol. 96 No. 1, pp. 369-386.

Grossman, S. and Hart, O. (1988), "One-share-one-vote and the market for corporate control”, Journal of Financial Economics, Vol. 20 Nos 1-2, pp. 175-202. 
IJOEM

15,2

Gupta, N. (2005), "Partial privatization and firm performance", Journal of Finance, Vol. 60 No. 2, pp. 987-1015.

Guriev, S. and Rachinsky, A. (2005), "The role of oligarchs in Russian capitalism”, Journal of Economic Perspectives, Vol. 19 No. 1, pp. 131-150.

Hillman, A.J. (2005), "Politicians on the board of directors: do connections affect the bottom line?", Journal of Management, Vol. 31 No. 3, pp. 464-481.

Iwasaki, I. (2007), "Legal forms of joint stock companies and corporate behavior in Russia", Problems of Economic Transition, Vol. 50 No. 5, pp. 73-86.

Jensen, M. and Meckling, W. (1976), "Theory of the firm: managerial behavior, agency costs, and ownership structure", Journal of Financial Economics, Vol. 3 No. 4, pp. 305-350.

Kay, J.A. and Thompson, D.J. (1986), "Privatization: a policy in search of a rationale", The Economic Journal, Vol. 96 No. 381, pp. 18-38.

Kuznetsov, P. and Muravyev, A. (2001), "Ownership concentration and firm performance in Russia: the case of blue chips of the stock market”, Acta-Oeconomica, Vol. 51 No. 4, pp. 469-488.

La Porta, R., Lopez-de-Silanes, F. and Shleifer, A. (1999), "Corporate ownership around the world", Journal of Finance, Vol. 54 No. 2, pp. 471-517.

La Porta, R., Lopez-de-Silanes, F., Shleifer, A. and Vishny, R. (1998), "Law and finance", Journal of Political Economy, Vol. 106 No. 6, pp. 1113-1155.

Lazareva, O., Rachinsky, A. and Stepanov, S. (2007), "A survey of corporate governance in Russia", Corporate Governance in Transition Economies III, Springer, Boston, MA, pp. 315-349.

Lazzarini, S.G. and Musacchio, A. (2018), "State ownership reinvented? Explaining performance differences between state-owned and private firms", Corporate Governance: An International Review, Vol. 26 No. 4, pp. 255-272, available at: https://doi.org/10.1111/corg.12239

Lee, J. (2009), "Does size matter in firm performance? Evidence from US public firms", International Journal of the Economics of Business, Vol. 16 No. 2, pp. 189-203.

Maury, B. and Liljeblom, E. (2009), "Oligarchs, political regime changes, and firm valuation", Economics of Transition, Vol. 17 No. 3, pp. 411-438.

Maury, B. and Pajuste, A. (2005), "Multiple large shareholders and firm value", Journal of Banking and Finance, Vol. 29 No. 7, pp. 1813-1834.

Megginson, W.L., Nash, R.C. and Randenborgh, V.M. (1994), "The financial and operating performance of newly privatized firms: an international empirical analysis", Journal of Finance, Vol. 49 No. 2, pp. 403-452.

Muravyev, A. (2002), "Federal state shareholdings in Russian companies: Origin, forms and consequences for enterprise performance", BOFIT Discussion Papers No. 12, Bank of Finland, Helsinki.

Nelson, L. and Kuzes, I. (2002), "Regional variations in the implementation of Russia's federal district reform”, Demokratizatsiy: The Journal of Post-Soviet Democratization, Vol. 10 No. 1, pp. 5-18.

OECD (2008), "The role of state-owned enterprises in the economy: an initial review of the evidence", Directorate for financial and enterprise affairs steering group on corporate governance, DAF/ CA/PRIV(2008)9, available at: www.oecd.org/officialdocuments/publicdisplaydocumentpdf/? cote $=\mathrm{DAF} / \mathrm{CA} / \mathrm{PRIV}(2008) 9 \&$ docLanguage $=$ En (accessed January 29, 2017).

OECD (2015), OECD Guidelines on Corporate Governance of State-Owned Enterprises, OECD Publications, Paris.

Okhmatovskiy, I. (2010), "Performance implications of ties to the government and SOEs: a political embeddedness perspective”, Journal of Management Studies, Vol. 47 No. 6, pp. 1020-1047.

Okhmatovskiy, I. and David, R.J. (2012), "Setting your own standards: internal corporate governance codes as a response to institutional pressure”, Organization Science, Vol. 23 No. 1, pp. 155-176.

Pinto, B. and Ulatov, S. (2010), "Financial globalization and the Russian crisis of 1998", The World Bank Policy Research Working Paper No. 5312, Washington, DC. 
Pöyry, S. and Maury, B. (2010), "Influential ownership and capital structure", Managerial and Decision Economics, Vol. 31 No. 5, pp. 311-324.

Puffer, S.M. and McCarthy, D.J. (2007), "Can Russia's state-managed, network capitalism be competitive? Institutional pull versus institutional push", Journal of World Business, Vol. 42 No. 1, pp. 1-13.

Remington, T. (2012), "Politics in Russia”, Chapter 3: Russia's Constitutional Order, 7th ed., Routledge, New York, NY, pp. 73-75.

Sharafutdinova, G. and Kisunko, G. (2014), "Governors and governing institutions: a comparative study of state-business relations in Russia's regions", Policy Research Working Paper No. WPS 7038, World Bank Group, Washington, DC.

Shleifer, A. (1998), "State versus private ownership", Journal of Economic Perspectives, Vol. 12 No. 4, pp. 133-150.

Shleifer, A. and Vishny, R. (1994), "Politicians and firms", Quarterly Journal of Economics, Vol. 109 No. 4, pp. 955-1025.

Shleifer, A. and Vishny, R. (1997), “A survey of corporate governance”, Journal of Finance, Vol. 52 No. 2, pp. 737-783.

Sprenger, C. (2010), "State ownership in the Russian economy: its magnitude, structure and governance problems", The Journal of the Institute of Public Enterprise, Vol. 33 Nos 1-2, pp. 63-110.

Sun, Q., Ting, W.H.S. and Tong, J. (2002), "How does government ownership affect firm performance? Evidence from China's privatization experience", Journal of Business Finance \& Accounting, Vol. 29 Nos 1-2, pp. 1-27.

Tompson, W. (2008), "Back to the future? Thoughts on the political economy of expanding state ownership in Russia", The Russia Papers No. 6, CERI Science Po, Paris.

Treisman, D. (2010), “'Loans for shares' revisited”, Post-Soviet Affairs, Vol. 26 No. 3, pp. 207-227.

Vanteeva, N. and Hickson, C. (2016), "The effect of state-private co-partnership system on Russian industry", Review of Industrial Organization, Vol. 48 No. 3, pp. 333-356.

Vining, A.R. and Weimer, D.L. (2016), "The challenges of fractionalized property rights in public-private hybrid organizations: the good, the bad, and the ugly", Regulation \& Governance, Vol. 10 No. 2, pp. 161-178.

Wang, W. (2015), "Impact of western sanctions on Russia in the Ukraine crisis", Journal of Politics and Law, Vol. 8 No. 2, pp. 1-6.

Wei, Z., Varela, O. and Hassan, M.K. (2002), "Ownership and performance in Chinese manufacturing industry", Journal of Multinational Financial Management, Vol. 12 No. 1, pp. 61-78.

World Bank (2017), “Doing business 2017: equal opportunity for all”, A World Bank Group Flagship Report, 14th ed., Washington, DC.

Yu, M. (2013), "State ownership and firm performance: empirical evidence from Chinese listed companies", China Journal of Accounting Research, Vol. 6 No. 2, pp. 75-87.

\section{Further reading}

Hess, K., Gunasekarage, A. and Hovey, M. (2010), "State-dominant and non-state-dominant ownership concentration and firm performance: evidence from China", International Journal of Managerial Finance, Vol. 6 No. 4, pp. 264-289.

\section{Corresponding author}

Benjamin Maury can be contacted at: benjamin.maury@hanken.fi

For instructions on how to order reprints of this article, please visit our website:

www.emeraldgrouppublishing.com/licensing/reprints.htm

Or contact us for further details: permissions@emeraldinsight.com 